\title{
Analysis of the chemical composition of organic aerosol at the Mt. Sonnblick observatory using a novel high mass resolution thermal-desorption proton-transfer-reaction mass-spectrometer (hr-TD-PTR-MS)
}

\author{
R. Holzinger ${ }^{1}$, A. Kasper-Giebl ${ }^{2}$, M. Staudinger ${ }^{3}$, G. Schauer ${ }^{3}$, and T. Röckmann ${ }^{1}$ \\ ${ }^{1}$ Institute for Marine and Atmospheric research Utrecht, Princetonplein 5, 3584 CC, Utrecht, The Netherlands \\ ${ }^{2}$ Vienna Univ. Technol., Inst. Chem. Technol. a. Analytics, Vienna, Austria \\ ${ }^{3}$ Cent. Inst. Meteorol. \& Geodynam., Vienna, Austria
}

Received: 29 April 2010 - Published in Atmos. Chem. Phys. Discuss.: 7 June 2010

Revised: 11 October 2010 - Accepted: 12 October 2010 - Published: 27 October 2010

\begin{abstract}
For the first time a high mass resolution thermal desorption proton transfer reaction mass spectrometer (hrTD-PTR-MS) was deployed in the field to analyze the composition of the organic fraction of aerosols. We report on measurements from the remote Mt. Sonnblick observatory in the Austrian alps (3108 ma.s.l.) during a 7 week period in summer 2009. A total of 638 mass peaks in the range 18-392 Da were detected and quantified in aerosols. An empirical formula was tentatively attributed to 464 of these compounds by custom-made data analysis routines which consider compounds containing $\mathrm{C}, \mathrm{H}, \mathrm{O}, \mathrm{N}$, and $\mathrm{S}$ atoms. Most of the other (unidentified) compounds must contain other elements - most likely halogenated compounds. The mean total concentration of all detected compounds was $1.1 \mu \mathrm{g} \mathrm{m}^{-3}$. Oxygenated hydrocarbons constitute the bulk of the aerosol mass $(75 \%)$ followed by organic nitrogen compounds (9\%), inorganic compounds (mostly $\mathrm{NH}_{3}, 8 \%$ ), unidentified/halogenated (3.8\%), hydrocarbons (2.7\%), and organic sulfur compounds $(0.8 \%)$. The measured $\mathrm{O} / \mathrm{C}$ ratios are lower than expected and suggest a significant effect from charring. Organic carbon concentrations measured with TDPTR-MS were about $25 \%$ lower than measurements on high volume filter samples.
\end{abstract}

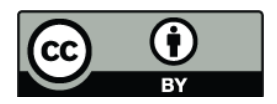

Correspondence to: R. Holzinger (r.holzinger@uu.nl)

\section{Introduction}

Health issues and climate effects are the two fundamental reasons why carbonaceous aerosol pollution is of concern. Many organic species in aerosols are carcinogenic and/or the cause of respiratory illnesses (e.g. Bascom et al., 1996; Pöschl et al., 2005; Mauderly and Chow, 2008; Hallquist et al., 2009). Besides direct reflection of solar radiation, aerosol pollution strongly alters cloud properties and the processes leading to cloud formation (Charlson et al., 1992; Andreae and Crutzen, 1997). While sulfate aerosol and most of the organic aerosol (OA) is considered purely reflecting, black carbon is a strong absorber of shortwave radiation and can alter the energy balance on micro scales (Jacobson, 2001; Ramanathan and Carmichael, 2008). Under conditions of cloud formation, larger numbers of fine aerosol result in smaller cloud droplets and such altered clouds are less likely to precipitate which constitutes a major feedback to the hydrological cycle (Andreae and Rosenfeld, 2008; Ramanathan et al., 2001; Rosenfeld et al., 2008). Of all these effects we have a sound qualitative understanding, however, for properly assessing the associate climate effects, better understanding of the sources of organic aerosols and their physicochemical processing is needed.

The source strength of secondary organic aerosol (SOA) has been estimated by scaling up aerosol yields from photooxidation of aerosol precursors. Such bottom up approaches yield SOA aerosol budgets of order $70 \mathrm{TgC}$ per year (Kanakidou et al., 2005). This is in discrepancy to SOA budgets of $150-900 \mathrm{TgC}$ per year that are obtained from top down

Published by Copernicus Publications on behalf of the European Geosciences Union. 
approaches (Hallquist et al., 2009; Goldstein and Galbally, 2007). The lower SOA budgets are also in contrast to field measurements where the organic aerosol fraction typically exceeds the sulfate fraction at sites that are not in direct vicinity of large sulfate sources (Jimenez et al., 2009). New conceptual frameworks that consider a close relationship between gas phase chemistry of semivolatile organic compounds and their partitioning into the aerosol phase have improved our understanding in the recent years (e.g. Donahue et al., 2006; Robinson et al., 2007; Jimenez et al., 2009). Many critical areas have been identified where better process-based understanding is still required. Important examples are better chemical speciation of OA, the physics and chemistry of particle nucleation, and aerosol cloud interactions (Hallquist et al., 2009).

Recently we presented a new analytical approach that combines the strengths of conventional proton transfer reaction mass spectrometry (PTR-MS) with impactor particle sampling (Holzinger et al., 2010). The new technique has been shown to detect about $\sim 80 \%$ of the aerosol mass that has been produced in smog chamber experiments from photooxidation of isoprenoids. The sensitivity of the instrument has been further improved and it now also features the high mass resolution capabilities of a time of flight mass spectrometer. Here we present first results that have been obtained during a 7-week campaign of measurements at the Mount Sonnblick observatory in the Austrian Alps. Computing the large amounts of experimental raw data is a practical challenge that needs to be met when evaluating data from the new instrument. The applied methods and routines are explained in appendices at the end of this article.

\section{Experimental}

\subsection{Site and meteorological situation}

The measurements took place at the Mt. Sonnblick observatory $\left(12.95^{\circ} \mathrm{E}, 47.05^{\circ} \mathrm{N}, 3105 \mathrm{~m}\right.$ a.s.1.) in the Austrian Alps in the period 10 July to 31 August 2009. Standard measurements at the observatory include meteorological parameters such as air temperature, humidity (relative humidity and dew point), wind speed and direction, precipitation (at the site and in the surrounding), shortwave radiation, ground temperature and permafrost in the vicinity of the summit.

The July measurement period was characterized by changing weather patterns with anticyclonic conditions with strong convection from lower levels from 10 to 16 July and a cold front passage from the west on 18 July, which brought snow fall down to $1000 \mathrm{~m}$ in the vicinity of the observatory, a strong vertical mixing and an efficient washout for all aerosols. The general circulation changed to southwest in the following days and anticyclonic, warmer than average conditions with occasional showers prevailed until the end of the month.
In August 2009 temperatures remained above average $\left(2.4^{\circ} \mathrm{C}\right)$, with a higher number than usual clear weather days and significantly more than average (131\%) sunshine hours. Dispersion conditions therefore were characterized by frequent nocturnal inversions between the adjacent valley and the observatory and strong convection during daytime with the advection of air masses from lower altitudes. The second characteristic element was the absence of longer dry periods which would usually allow the accumulation of aerosols over larger air masses. The longest precipitation free periods were 5-7, 18-20 and 23-25 August.

Typical origins of pollution at the Sonnblick site are the industrial areas in southern and middle Germany, most parts of North-Eastern Europe and the northern parts of Italy around the Milan agglomeration. Local sources of pollution reach the Sonnblick site during convective mixing phases especially at daytime when the mixing height surpasses the observatory altitude.

\subsection{Instrument description}

The general setup of the instrument used in this study is similar to the one described by Holzinger et al. (2010). Briefly, humidified particles are collected on a Collection-ThermalDesorption (CTD) cell from which aerosol compounds are thermally released by ramping the temperature up to $350^{\circ} \mathrm{C}$ in steps of $50^{\circ} \mathrm{C}$. Evaporating aerosol compounds are transported through heated transfer lines from the CTD cell to the detector using pure nitrogen as carrier gas. Organic and some inorganic aerosol species are detected by PTR-MS. For a detailed description of the aerosol sampling system we refer to Williams et al. (2006), for more I nformation on PTR-MS we refer to Lindinger et al. (1998), and Hansel et al. (1999), and for a general description of the TD-PTR-MS technique we refer to Holzinger et al. (2010).

The use of PTR-MS as detector for aerosol compounds is highly advantageous for the following reasons: (i) PTR-MS is a relatively soft ionization technique; many compounds do not fragment and are detected at their protonated mass (molecular weight +1$)$. If fragmentation occurs it often follows a well-defined pattern such as the loss of an $\mathrm{H}_{2} \mathrm{O}$ fragment in the case of higher alcohols. (ii) PTR-MS is very sensitive and therefore low detection limits in aerosol analysis can be achieved. (iii) Virtually all compounds constituting the "organic carbon" fraction in aerosols can be detected, and (iv) although compounds are only identified by their mass to charge ratio in the mass spectrometer they can still be quantified at the $\sim 30 \%$ accuracy level because of the welldefined conditions in the drift tube and the fact that protontransfer reaction rates are usually close to the ion-molecule collision rate when a reaction is energetically possible. Using PTR-MS as detector for aerosol compounds it is possible to directly measure and quantify the total amount of organic aerosol; however, some reservations remain with respect to fragmentation. Especially alkanes and alkenes have been 
shown to produce relative low molecular weight fragments upon protonation (Jobson et al., 2005) and therefore a large mass fraction of such compounds remains neutral and thus undetected.

While state of the art online/in situ aerosol techniques such as aerosol mass spectrometry (AMS, Jayne et al., 2000) and thermal desorption aerosol gas chromatography (TAG, Williams et al., 2006) have contributed a great deal to the current understanding of aerosol sources and processing, the TD-PTR-MS instrument has genuine advantages that warrant pursuing this technique. TAG and TD-PTR-MS rely on the same technology for aerosol sampling, however, the TAG provides no thermogram information because all aerosol components are released at once into the GC column. Furthermore gas chromatography is a rather selective detector that resolves probably less than $10 \%$ of the total organic burden. AMS on the other hand, features fast and size resolved aerosol measurements. However, the technique relies on electron ionization which causes extensive fragmentation of aerosol compounds and much of the chemical information is thus lost. Both, AMS and TAG, rely on aerosol standards for quantification of their respective signals.

A schematic drawing of the instrument is given in Fig. 1. In the following we describe the key differences to the setup from Holzinger et al. (2010): most importantly, as detector of organic vapors we used the novel PTR-TOF-MS instrument (Jordan et al., 2009; Graus et al., 2010). The excellent mass resolution capability of this instrument $\left(m / \Delta m_{\mathrm{FWHM}} \sim 5000\right.$ under "V-mode" field operation conditions, where $\Delta m_{\mathrm{FWHM}}$ is the full width at half maximum of the peak) allows identifying the signals by their empirical formula rather than by integer molecular weight numbers. The enhanced chemical speciation allows for direct measurement of atomic $\mathrm{O} / \mathrm{C}$ and $\mathrm{N} / \mathrm{C}$ ratios. Again some reservations remain with respect to fragmentation because these ratios can be biased if e.g. the undetected, neutral fragments contain disproportionally more oxygen atoms.

Furthermore, the instrument is equipped with a second aerosol inlet system which has been used to increase the time resolution of the in-situ aerosol measurements. Possible alternative applications of the second inlet include (i) the analysis of different size fractions (by using different precutoffs in front of the inlet), (ii) measurement of ecosystem fluxes of aerosol compounds by disjunct eddy covariance, and (iii) analysis of the influence of other physicochemical pre-treatment on the composition of ambient organic aerosol (thermodenuder, cloud processing, etc.). The third significant improvement is the capability to measure reliable field blanks for both aerosol and gas phase measurements. Gas phase field blanks were measured by providing excess zero air (i.e. ambient outside air cleaned using a Platinum catalyst operated at $350{ }^{\circ} \mathrm{C}$ ) at the entrance of the gas phase inlet. Aerosol field blanks were measured by passing airstream through a Teflon membrane filter (Zefluor $2.0 \mu \mathrm{m}$, Pall Corp.) during aerosol collection. The effective removal of parti-

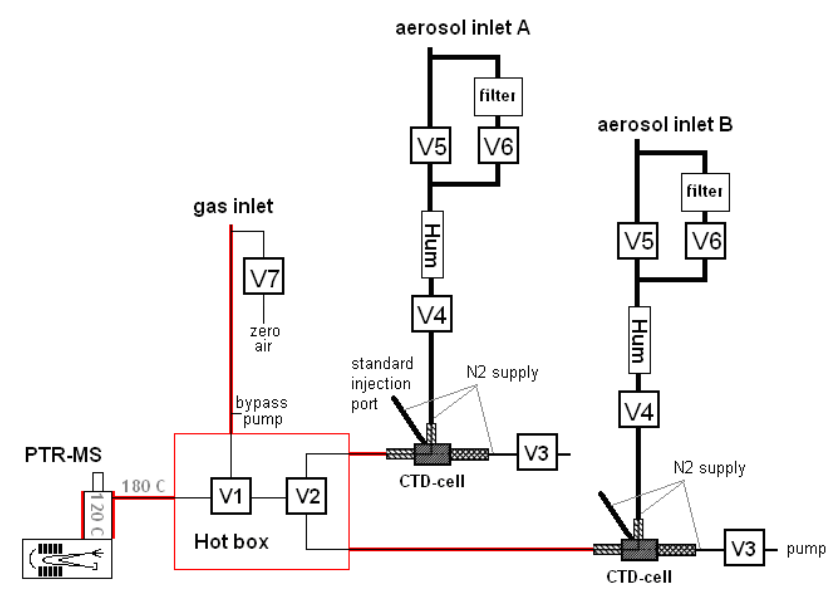

Fig. 1. Schematic drawing of the setup. If not indicated otherwise, all areas marked in red were operated at high temperatures of $200^{\circ} \mathrm{C}$. Note that during this campaign the gas inlet was NOT heated outside the building.

cles was confirmed by test measurements with a condensation particle counter (TSI, WCPC Model 3785). This setup allowed a more reliable determination of the instrumental background including the contamination of the CTD cell by semivolatile gas phase compounds. While particles are removed by the Teflon filter, gas phase compounds should be less affected. This way contamination from semivolatile gas phase compounds on the aerosol measurement can be corrected for, although some artifacts may still persist. Last but not least the performance of the instrument has been improved by increasing the aerosol collection flow from 0.9 to 9 liter per minute which results in increased sensitivity of a factor of 10 .

A potential issue is the lower operating temperatures of the drift tube $\left(120^{\circ} \mathrm{C}\right)$ and the transfer line from the sampling unit to the PTR-MS $\left(180^{\circ} \mathrm{C}\right)$. Aerosol compounds vaporized at high temperatures may re-condense to these surfaces with the effect that fractions of low-volatility compounds are not detected and background contamination is built up in the long term. However, both the regions are operated at low pressures of a few $\mathrm{hPa}$ which helps reducing the problem.

There are two basic operation modes of the aerosol inlets: the "load-mode" and the "analysis-mode". In the "loadmode" valves 3, 4, and 5 are open; a flow of 9 liter per minute passes the CTD cell (see Fig. 1), and aerosols are collected on a small spot in the cell. An aerosol blank can be prepared by passing the air stream through the filter (valve 5 closed and valve 6 open). While one CTD cell is loaded the PTR-MS can either measure the gas phase or analyze the other CTD cell. In the "analysis-mode" valves 3 and 4 are closed and the CTD cell is directly connected to the PTR-MS via valves 1 and 2 . Following a predefined temperature program the CTD cell is heated to the final temperature. The small flow of $\mathrm{N}_{2}$ carrier gas $(\sim 0.01$ standard liters per minute, SLM) 
transports the vaporized aerosol compounds to the PTR-MS and maintains the pressure in the PTR-MS drift tube.

The PTR-TOF-MS was typically operated at a pressure of $2.6 \mathrm{hPa}$ in the drift tube and an E/N value $100 \mathrm{Td}$. The calculation of aerosol concentrations and gas phase volume mixing ratios (VMR) has been described in Holzinger et al. (2010).

\section{Field configuration of the instrument}

At the Mount Sonnblick observatory, the TD-PTR-MS system was located inside the building and the aerosols were sampled from the roof of the building via a $10 \mathrm{~m}$ long copper line $(\mathrm{ID}=6.5 \mathrm{~mm})$. Coarse particles were removed by a $\mathrm{PM}_{2.5}$ cyclone (10 Lpm, URG-2000-30EN, URG Corporation, Chapel Hill, USA). The gas phase inlet was located next to the aerosol inlet and consisted of a $10 \mathrm{~m}$ PEEK tubing (ID $=1 \mathrm{~mm}$ ). Lightning protection is a serious issue at this site and therefore it was not possible to heat the lines outside the protected building, furthermore the aerosol lines passed a short distance of $10 \mathrm{~cm}$ through a Teflon line (PFA, $\mathrm{ID}=6.5 \mathrm{~cm}$ ) in order to electrically separate parts inside and outside the building. During the campaign several blackouts were caused by direct lightning strokes. The essential parts of the system were protected with an uninterruptible power supply (UPS).

Figure 2 shows $24 \mathrm{~h}$ of PTR-MS-data for 3 measured ion species and also illustrates the sampling scheme that was used for the largest part of the campaign (starting from day 202, i.e. 22 July 2009): (i) $30 \mathrm{~min}$ measurement of gas phase background, (ii) 45 min measurement of gasphase, (iii) 30 min measurement of gas phase background, (iv) 45 min measurement of gasphase, (v) 43 min analysis inlet A, (vi) 4 min measurement of gas phase background, and (vii) $43 \mathrm{~min}$ analysis inlet B. Prior to analysis, aerosols have been sampled for 150 and 165 min for inlet A and B, respectively. The actual flow through the CTD cells was measured with a mass flow meter (1479A series, MKS instruments) to accurately calculate the sampled air volume. The aerosol background and/or interference from gas phase compounds was followed closely by measuring a field blank every second aerosol run. For aerosol analysis the CTD cell was stepwise heated to temperature levels of 50,100, 150, 200, 250, 300, and $350^{\circ} \mathrm{C}$. Each temperature level was completed in $6 \mathrm{~min}$ (which roughly implies 2 min for ramping and a dwell time of $4 \mathrm{~min}$ ); a peak of vaporized aerosol species is associated with every temperature level (see insert in Fig. 2).

During the whole campaign the instrument measured mass scans at a rate of $35 \mu \mathrm{s}$ per scan corresponding to a mass range of $10-430 \mathrm{Da}$; data were saved at $5 \mathrm{~s}$ time resolution. In the first days of the campaign (before 22 July 2009) a slightly different cycling was applied. The most important difference was that aerosol field blanks were measured not every second but only every fourth aerosol run.
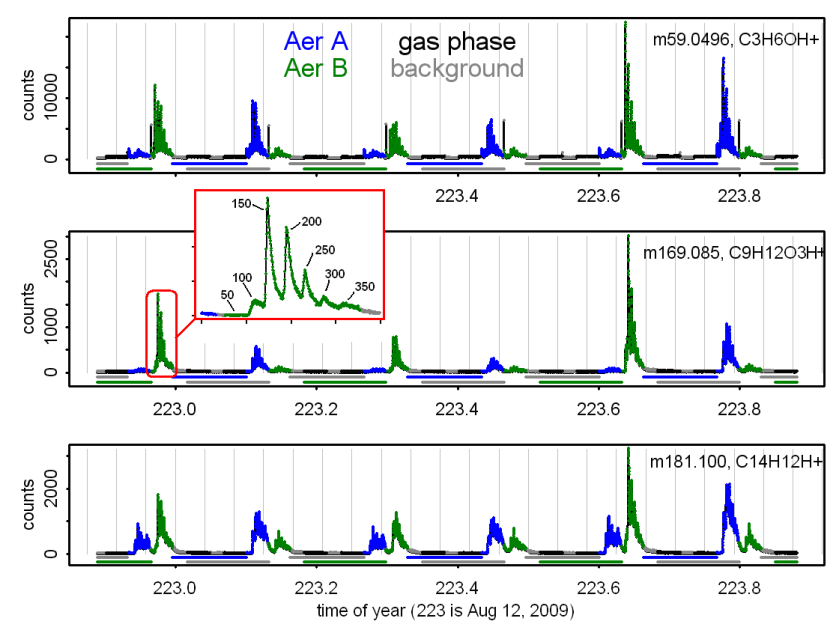

Fig. 2. TD-PTR-MS data of 3 ion species over period of $24 \mathrm{~h}$. Gas phase measurements are printed in black; when zero-air was supplied to the gas inlet the data are printed in grey (background measurement). Blue and green data indicate that aerosol inlet A and B was analysed, respectively. The lines just above the time axis indicate the times of aerosol sampling, the upper line for inlet A and the lower line for inlet B. Grey lines indicate that the sample flow was directed through the aerosol filter (field blank). The peaks associated with temperature levels during aerosol analysis are clearly visible in the insert (the numbers in the insert indicate the CTD cell temperature).

For the analysis presented in the "results and discussion" section we only use data from the aerosol inlet B. Prior to the field campaign at the Mt. Sonnblick observatory aerosol inlet A was intensively used during a test campaign and it turned out that it was not sufficiently cleaned before the Mt. Sonnblick measurements. As a result the field blanks for this inlet are high on many peaks. After blank correction, the results from inlets $\mathrm{A}$ and $\mathrm{B}$ are in reasonable agreement but because of the known issues we focus on the analysis on data from aerosol inlet B which was clean and used for the first time during this campaign. Meanwhile we established a thorough cleaning protocol for the aerosol inlets.

\subsection{Other measurements}

Filter sampling was performed with a Digitel High Volume Sampler on quartz fiber filters (Pallflex, $150 \mathrm{~mm}$ ). Sampling intervals were $166 \mathrm{~h}$ (close to 7 days) with sample change at approximately 08:30 in the morning of the first day of the sampling interval. For the determination of the Total Carbon (TC) aliquots of the filters were combusted in a vertical furnace at $1000^{\circ} \mathrm{C}$ in an oxygen stream with subsequent detection of the evolving carbon dioxide with a NDIR monitor (Maihak SIFOR 200). Analysis of Elemental Carbon (EC) is based on a method described by Cachier et al. (1989). Aliquots of the filters are heated to $340^{\circ} \mathrm{C}$ in an oxygen atmosphere for two hours to remove all organic material. The 


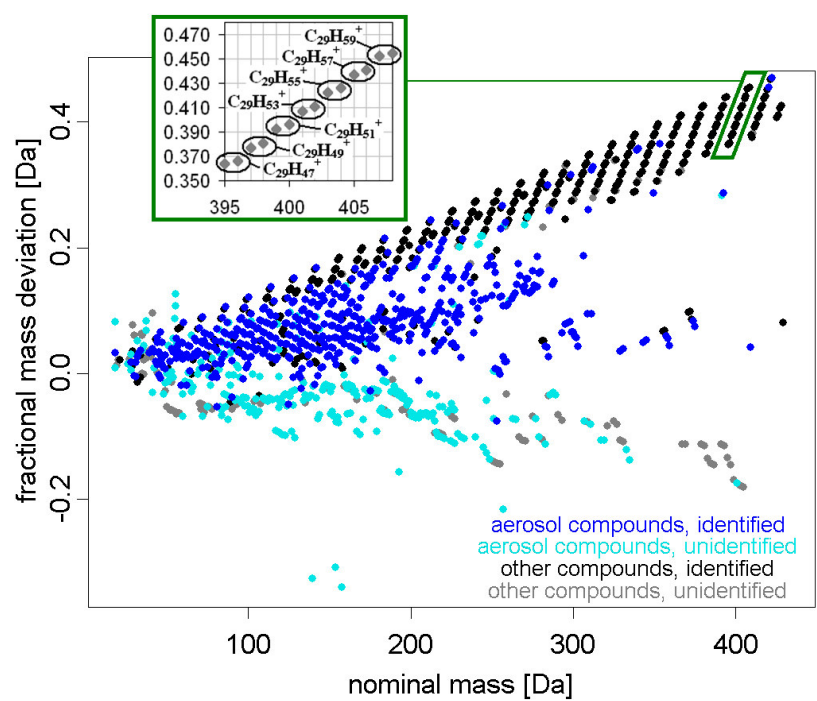

Fig. 3. All 1210 mass peaks of the unified-peak-list. The hydrocarbons clearly stand out as straight line in the Figure. The insert enlarges the $\mathrm{C}_{29}$ hydrocarbons. Note that for these hydrocarbon series typically the two most abundant isotopologues were detected (i.e. the one containing only ${ }^{12} \mathrm{C}$ atoms, and the species containing one ${ }^{13} \mathrm{C}$ atom.). To the left and right of the $\mathrm{C}_{29}$ line are the $\mathrm{C}_{28}$ and the $\mathrm{C}_{30}$ lines, respectively. Oxygenated compounds are below the hydrocarbons on the graph because they are typically lighter $\left(m_{\mathrm{CH}_{4}}-m_{\mathrm{O}}=36.4 \mathrm{mDa}\right)$. Peaks printed in blue or cyan were significantly enhanced in aerosols. Peaks printed in blue and black were identified by their empirical formula; peaks printed in cyan and grey were only identified by their molecular weight. Note that most high molecular weight hydrocarbon signals were not detected in aerosols but due to instrumental background.

remaining carbon is defined as EC and is quantified as described above for TC. Organic Carbon (OC) is calculated as TC - EC. The exact details of the methods have been described by Jankowski et al. (2008).

\section{Data processing}

The two key advantages of the time of flight (TOF) over a conventional quadrupole mass spectrometer are (i) the high mass resolution and (ii) that always full mass scan information is available without compromising sensitivity and time resolution. Ions were pulsed every $35 \mu$ s into the TOF region. At the end of the flight region incoming ions are scanned at a frequency of $5 \mathrm{GHz}$ (i.e. $0.2 \mathrm{~ns}$ bins). To achieve a time resolution of $5 \mathrm{~s}, 142860$ initial mass spectra have been added and stored as one cycle into a data file. Every data file contained 900 such cycles, which is 75 min worth of data. Each cycle contains 175499 data points (i.e. the signal in the individual $0.2 \mathrm{~ns}$ bins), thus the size of a single data file is $\sim 160$ million double-precision floating-point values; typically $50 \mathrm{MB}$ in the compressed HDF5 format. In addition, engineering data such as pressures, flows, voltages, temperatures and valve positions, and a cumulative sum-spectrum of all cycles in a file are saved as well. A total of 1022 data files have been created during the campaign.

Data processing was done in IDL (Version 7.0.0, ITT Visual Information Solutions) and includes the following five fundamental routines which are described in Appendices A$\mathrm{E}$ at the end of this article:

a. Time to mass conversion: cycle-to-cycle computation of the parameters for converting the time scale of $0.2 \mathrm{~ns}$ bins to an ion mass scale.

b. Peak detection: create a "peak list" for individual files.

c. Homogenization: the derived mass for a detected ion may vary a few $\mathrm{mDa}$ from file to file due to statistical uncertainty and the limited mass resolution of the mass spectrometer. The homogenization routine creates a "unified-peak-list"; the overall mass accuracy of the detected ions is improved.

d. Integration and correction of overlapping signals: peak margins are defined and the signal within the margins is summed up. Each peak is associated with a timeline of counts. If neighbouring peaks are not fully resolved their signals are corrected for contributions from the overlapping peaks.

e. Mass scale re-calibration and peak identification: it was possible to re-calibrate the mass scale by exploiting the ion signals of homologous hydrocarbon series which were part of the instrumental background contamination. With this treatment a mass accuracy of $\pm 3 \mathrm{mDa}$ was achieved. Within this accuracy empirical formulas were attributed.

Our goal was to create routines allowing for a full analysis of TOF mass scan data (as opposed to evaluating single peaks of interest) over longer periods of time at sufficient low computational cost so that the analysis can be done with common personal computers. The routines reliably identified the major ion species (more than 1200) that were observed during the field campaign. 638 of these species are original aerosol compounds (Table 1, and Supplement). Of the remaining compounds most of the signal is probably due to instrumental background. Almost certainly there are still additional low signal peaks which do not emerge from the tailing of neighbouring larger peaks. A peak shape analysis and non linear least square fitting of overlapping signals similar to DeCarlo et al. (2006) or Müller er al. (2010) could resolve many yet unresolved peaks and is subject to future development of our evaluation tools package. 
Table 1. Basic information on the 40 most abundant and 10 least abundant aerosol compounds. A full list of all 638 detected compounds is given in the supplemental information.

\begin{tabular}{|c|c|c|c|c|c|c|}
\hline Peak ID & $\begin{array}{l}\text { Measured } \\
\text { mass }[\mathrm{Da}]\end{array}$ & $\begin{array}{l}\text { Possible empirical } \\
\text { formulas }^{\mathrm{a}}\end{array}$ & $\begin{array}{l}\text { Temp largest } \\
\text { signal }\end{array}$ & $\begin{array}{l}\text { Mean concentration } \\
\text { throughout the campaign } \\
{\left[\mathrm{ng} / \mathrm{m}^{3}\right]^{\mathrm{b}}}\end{array}$ & $\begin{array}{l}\text { LOD } \\
{\left[\mathrm{ng} / \mathrm{m}^{3}\right]}\end{array}$ & $\begin{array}{l}\text { Fraction } \\
\text { of total } \\
\text { burden (rank) }\end{array}$ \\
\hline $\mathrm{m} 18.0321$ & 18.033 & $\mathrm{NH}_{3} \mathrm{H}^{+}(-0.5)$ & 150 & $90,(2.4,79,177)$ & n.c. & $8.06 \%(1)$ \\
\hline $\mathrm{m} 43.0180$ & 43.018 & $\mathrm{C}_{2} \mathrm{H}_{2} \mathrm{OH}^{+}(0.3)$ & 150 & $7.0,(0.19,5.8,15.9)$ & 0.365 & $0.63 \%(39)$ \\
\hline $\mathrm{m} 45.0336$ & 45.034 & $\mathrm{C}_{2} \mathrm{H}_{4} \mathrm{OH}^{+}(0.2)$ & 200 & $9.3,(0.53,9.1,17.9)$ & 0.419 & $0.83 \%(27)$ \\
\hline $\mathrm{m} 47.0133$ & 47.013 & $\mathrm{CH}_{2} \mathrm{O}_{2} \mathrm{H}^{+}(0.6)$ & 150 & $10.4,(0.46,10.5,18.7)$ & 0.124 & $0.94 \%(24)$ \\
\hline m59.0496 & 59.049 & $\mathrm{C}_{3} \mathrm{H}_{6} \mathrm{OH}^{+}(0.1)$ & 100 & $25,(0.9,20,58)$ & 0.440 & $2.23 \%(5)$ \\
\hline m59.9671 & 59.967 & & 100 & $0.007,(0.000,0.005,0.017)$ & 0.001 & $0.00065 \%(630)$ \\
\hline m61.0291 & 61.029 & $\mathrm{C}_{2} \mathrm{H}_{4} \mathrm{O}_{2} \mathrm{H}^{+}(0.3)$ & 200 & $33,(1.6,30,65)$ & 0.214 & $2.99 \%(3)$ \\
\hline m64.0042 & 64.004 & $\mathrm{HNO}_{3} \mathrm{H}^{+}(0.8)$ & 150 & $0.007,(0.000,0.004,0.014)$ & 0.002 & $0.00061 \%(631)$ \\
\hline $\mathrm{m} 70.0064$ & 70.006 & & 300 & $0.004,(0.000,0.003,0.009)$ & 0.002 & $0.00035 \%(638)$ \\
\hline $\mathrm{m} 73.0296$ & 73.029 & $\mathrm{C}_{3} \mathrm{H}_{4} \mathrm{O}_{2} \mathrm{H}^{+}(0.5)$ & 200 & $13.1,(1.22,13.6,23.9)$ & 0.125 & $1.18 \%(17)$ \\
\hline $\mathrm{m} 77.9933$ & 77.992 & $\mathrm{~N}_{2} \mathrm{O}_{3} \mathrm{H}^{+}(-2.7)$ & 150 & $0.005,(0.000,0.003,0.011)$ & 0.002 & $0.00042 \%(636)$ \\
\hline m79.9998 & 79.999 & $\mathrm{HNO}_{4} \mathrm{H}^{+}(1.1)$ & 150 & $0.004,(0.000,0.003,0.009)$ & 0.001 & $0.00039 \%(637)$ \\
\hline $\mathrm{m} 82.0060$ & 82.005 & & 150 & $0.006,(0.000,0.005,0.014)$ & 0.001 & $0.00057 \%(633)$ \\
\hline $\mathrm{m} 83.0503$ & 83.049 & $\mathrm{C}_{5} \mathrm{H}_{6} \mathrm{OH}^{+}(0.2)$ & 150 & $8.6,(0.27,6.7,16.9)$ & 0.189 & $0.77 \%(33)$ \\
\hline $\mathrm{m} 85.0297$ & 85.029 & $\mathrm{C}_{4} \mathrm{H}_{4} \mathrm{O}_{2} \mathrm{H}^{+}(0.3)$ & 150 & $8.2,(0.33,7.4,16.3)$ & 0.175 & $0.74 \%(35)$ \\
\hline $\mathrm{m} 87.0452$ & 87.044 & $\mathrm{C}_{4} \mathrm{H}_{6} \mathrm{O}_{2} \mathrm{H}^{+}(0.2)$ & 150 & $12.9,(0.42,11.5,25.4)$ & 0.080 & $1.15 \%(19)$ \\
\hline $\mathrm{m} 87.9261$ & 87.925 & & 150 & $0.007,(0.000,0.005,0.016)$ & 0.002 & $0.00061 \%(632)$ \\
\hline $\mathrm{m} 87.9629$ & 87.962 & & 150 & $0.009,(0.000,0.007,0.016)$ & 0.001 & $0.00077 \%(629)$ \\
\hline m97.0297 & 97.029 & $\mathrm{C}_{5} \mathrm{H}_{4} \mathrm{O}_{2} \mathrm{H}^{+}(0.2)$ & 250 & $13.4,(0.88,13.7,25.4)$ & 0.193 & $1.20 \%(16)$ \\
\hline $\mathrm{m} 99.0091$ & 99.008 & $\begin{array}{l}\mathrm{C}_{4} \mathrm{H}_{2} \mathrm{O}_{3} \mathrm{H}^{+}(0.4), \\
\mathrm{H}_{3} \mathrm{NO}_{5} \mathrm{H}^{+}(2.6)\end{array}$ & 200 & $20,(0.9,20,37)$ & 0.626 & $1.83 \%(10)$ \\
\hline m99.0449 & 99.044 & $\mathrm{C}_{5} \mathrm{H}_{6} \mathrm{O}_{2} \mathrm{H}^{+}(-0.2)$ & 150 & $22,(0.7,18,45)$ & 0.466 & $1.96 \%(7)$ \\
\hline $\mathrm{m} 101.025$ & 101.024 & $\mathrm{C}_{4} \mathrm{H}_{4} \mathrm{O}_{3} \mathrm{H}^{+}(0.6)$ & 150 & $36,(0.3,32,77)$ & 0.125 & $3.23 \%(2)$ \\
\hline m101.061 & 101.060 & $\mathrm{C}_{5} \mathrm{H}_{8} \mathrm{O}_{2} \mathrm{H}^{+}(0.2)$ & 150 & $9.2,(0.12,8.8,19.7)$ & 0.460 & $0.83 \%(28)$ \\
\hline m104.933 & 104.932 & & 150 & $0.005,(-0.001,0.003,0.011)$ & 0.002 & $0.00043 \%(635)$ \\
\hline m106.939 & 106.938 & & 150 & $0.005,(0.000,0.004,0.010)$ & 0.002 & $0.00044 \%(634)$ \\
\hline m111.046 & 111.045 & $\mathrm{C}_{6} \mathrm{H}_{6} \mathrm{O}_{2} \mathrm{H}^{+}(0.9)$ & 200 & $17.6,(0.54,15.3,38.0)$ & 0.132 & $1.57 \%(12)$ \\
\hline $\mathrm{m} 113.026$ & 113.025 & $\begin{array}{l}\mathrm{C}_{5} \mathrm{H}_{4} \mathrm{O}_{3} \mathrm{H}^{+}(1.7), \\
\mathrm{CH}_{5} \mathrm{NO}_{5} \mathrm{H}^{+}(-2.4)\end{array}$ & 200 & $15.3,(0.71,15.2,29.3)$ & 0.308 & $1.37 \%(14)$ \\
\hline m113.060 & 113.059 & $\mathrm{C}_{6} \mathrm{H}_{8} \mathrm{O}_{2} \mathrm{H}^{+}(-0.7)$ & 150 & $19.4,(0.38,16.4,38.8)$ & 0.521 & $1.74 \%(11)$ \\
\hline $\mathrm{m} 115.040$ & 115.039 & $\begin{array}{l}\mathrm{C}_{5} \mathrm{H}_{6} \mathrm{O}_{3} \mathrm{H}^{+}(0.0) \\
\mathrm{C}_{8} \mathrm{H}_{3} \mathrm{NH}^{+}(1.8)\end{array}$ & 150 & $13.6,(0.04,12.1,31.5)$ & 0.132 & $1.22 \%(15)$ \\
\hline $\mathrm{m} 115.076$ & 115.075 & $\mathrm{C}_{6} \mathrm{H}_{10} \mathrm{O}_{2} \mathrm{H}^{+}(-0.4)$ & 150 & $8.9,(0.09,7.9,18.9)$ & 0.099 & $0.80 \%(31)$ \\
\hline $\mathrm{m} 125.061$ & 125.060 & $\mathrm{C}_{7} \mathrm{H}_{8} \mathrm{O}_{2} \mathrm{H}^{+}(0.4)$ & 150 & $12.1,(0.31,9.3,25.2)$ & 0.161 & $1.08 \%(20)$ \\
\hline $\mathrm{m} 127.041$ & 127.040 & $\begin{array}{l}\mathrm{C}_{6} \mathrm{H}_{6} \mathrm{O}_{3} \mathrm{H}^{+}(1.1), \\
\mathrm{C}_{2} \mathrm{H}_{7} \mathrm{NO}_{5} \mathrm{H}^{+}(-2.9)\end{array}$ & 150 & $8.4,(0.06,7.8,17.0)$ & 0.155 & $0.75 \%(34)$ \\
\hline $\mathrm{m} 127.076$ & 127.075 & $\mathrm{C}_{7} \mathrm{H}_{10} \mathrm{O}_{2} \mathrm{H}^{+}(-0.2)$ & 200 & $20,(0.4,17,43)$ & 0.492 & $1.83 \%(9)$ \\
\hline $\mathrm{m} 129.056$ & 129.055 & $\begin{array}{l}\mathrm{C}_{6} \mathrm{H}_{8} \mathrm{O}_{3} \mathrm{H}^{+}(0.5) \\
\mathrm{C}_{9} \mathrm{H}_{5} \mathrm{NH}^{+}(2.3)\end{array}$ & 150 & $11.1,(0.10,9.2,24.3)$ & 0.362 & $0.99 \%(23)$ \\
\hline m139.041 & 139.040 & $\begin{array}{l}\mathrm{C}_{7} \mathrm{H}_{6} \mathrm{O}_{3} \mathrm{H}^{+}(1.3), \\
\mathrm{C}_{3} \mathrm{H}_{7} \mathrm{NO}_{5} \mathrm{H}^{+}(-2.8), \\
\mathrm{C}_{4} \mathrm{H}_{10} \mathrm{O}_{3} \mathrm{SH}^{+}(-2.0)\end{array}$ & 150 & $9.8,(0.39,8.6,19.3)$ & 0.183 & $0.88 \%(25)$ \\
\hline m139.075 & 139.074 & $\begin{array}{l}\mathrm{C}_{8} \mathrm{H}_{10} \mathrm{O}_{2} \mathrm{H}^{+}(-1.1), \\
\mathrm{C}_{3} \mathrm{H}_{10} \mathrm{~N}_{2} \mathrm{O}_{4} \mathrm{H}^{+}\end{array}$ & 200 & $11.5,(0.35,9.3,27.4)$ & 0.442 & $1.03 \%(21)$ \\
\hline m141.056 & 141.055 & $\begin{array}{l}\mathrm{C}_{7} \mathrm{H}_{8} \mathrm{O}_{3} \mathrm{H}^{+} \\
\mathrm{C}_{10} \mathrm{H}_{5} \mathrm{NH}^{+}\end{array}$ & 150 & $23,(0.4,18,46)$ & 0.261 & $2.02 \%(6)$ \\
\hline m141.090 & 141.089 & $\mathrm{C}_{8} \mathrm{H}_{12} \mathrm{O}_{2} \mathrm{H}^{+}(-1.7)$ & 150 & $7.3,(0.10,5.4,17.3)$ & 0.074 & $0.65 \%(37)$ \\
\hline $\mathrm{m} 143.072$ & 143.071 & $\begin{array}{l}\mathrm{C}_{7} \mathrm{H}_{10} \mathrm{O}_{3} \mathrm{H}^{+} \\
\mathrm{C}_{10} \mathrm{H}_{7} \mathrm{NH}^{+}(2.1)\end{array}$ & 150 & $9.5,(0.07,8.3,21.0)$ & 0.271 & $0.85 \%(26)$ \\
\hline m149.026 & 149.025 & $\begin{array}{l}\mathrm{C}_{8} \mathrm{H}_{4} \mathrm{O}_{3} \mathrm{H}^{+}(2.2), \\
\mathrm{C}_{4} \mathrm{H}_{5} \mathrm{NO}_{5} \mathrm{H}^{+}(-1.9)\end{array}$ & 150 & $9.1,(-0.51,8.7,19.8)$ & 0.049 & $0.82 \%(29)$ \\
\hline
\end{tabular}


Table 1. Continued.

\begin{tabular}{|c|c|c|c|c|c|c|}
\hline Peak ID & $\begin{array}{l}\text { Measured } \\
\text { mass }[\mathrm{Da}]\end{array}$ & $\begin{array}{l}\text { Possible empirical } \\
\text { formulas }^{\mathrm{a}}\end{array}$ & $\begin{array}{l}\text { Temp largest } \\
\text { signal }\end{array}$ & $\begin{array}{l}\text { Mean concentration } \\
\text { throughout the campaign } \\
{\left[\mathrm{ng} / \mathrm{m}^{3}\right]^{\mathrm{b}}}\end{array}$ & $\begin{array}{l}\text { LOD } \\
{\left[\mathrm{ng} / \mathrm{m}^{3}\right]}\end{array}$ & $\begin{array}{l}\text { Fraction } \\
\text { of total } \\
\text { burden (rank) }\end{array}$ \\
\hline $\mathrm{m} 153.057$ & 153.057 & $\begin{array}{l}\mathrm{C}_{8} \mathrm{H}_{8} \mathrm{O}_{3} \mathrm{H}^{+}(1.9), \\
\mathrm{C}_{4} \mathrm{H}_{9} \mathrm{NO}_{5} \mathrm{H}^{+}(-2.1), \\
\mathrm{C}_{5} \mathrm{H}_{12} \mathrm{O}_{3} \mathrm{SH}^{+}(-1.4)\end{array}$ & 150 & $6.9,(0.16,5.6,14.5)$ & 0.137 & $0.62 \%(40)$ \\
\hline $\mathrm{m} 153.091$ & 153.091 & $\mathrm{C}_{9} \mathrm{H}_{12} \mathrm{O}_{2} \mathrm{H}^{+}(-0.5)$ & 150 & $7.8,(0.03,5.6,18.1)$ & 0.146 & $0.70 \%(36)$ \\
\hline $\mathrm{m} 155.072$ & 155.072 & $\begin{array}{l}\mathrm{C}_{8} \mathrm{H}_{10} \mathrm{O}_{3} \mathrm{H}^{+}(1.3), \\
\mathrm{C}_{4} \mathrm{H}_{11} \mathrm{NO}_{5} \mathrm{H}^{+}(-2.8)\end{array}$ & 150 & $16.3,(0.09,12.3,37.7)$ & 0.140 & $1.46 \%(13)$ \\
\hline $\mathrm{m} 157.051$ & 157.051 & $\begin{array}{l}\mathrm{C}_{7} \mathrm{H}_{8} \mathrm{O}_{4} \mathrm{H}^{+} \\
\mathrm{C}_{10} \mathrm{H}_{5} \mathrm{NOH}^{+}\end{array}$ & 150 & $21,(0.0,16,49)$ & 0.164 & $1.86 \%(8)$ \\
\hline $\mathrm{m} 157.085$ & 157.085 & $\begin{array}{l}\mathrm{C}_{8} \mathrm{H}_{12} \mathrm{O}_{3} \mathrm{H}^{+}(-1.3) \\
\mathrm{C}_{11} \mathrm{H}_{9} \mathrm{NH}^{+}(0.5)\end{array}$ & 150 & $7.1,(0.05,5.8,16.5)$ & 0.374 & $0.64 \%(38)$ \\
\hline m169.085 & 169.085 & $\begin{array}{l}\mathrm{C}_{9} \mathrm{H}_{12} \mathrm{O}_{3} \mathrm{H}^{+}(-1.0), \\
\mathrm{C}_{12} \mathrm{H}_{9} \mathrm{NH}^{+}(0.8), \\
\mathrm{C}_{4} \mathrm{H}_{12} \mathrm{~N}_{2} \mathrm{O}_{5} \mathrm{H}^{+}(3.0)\end{array}$ & 150 & $9.1,(0.05,6.4,21.3)$ & 0.045 & $0.82 \%(30)$ \\
\hline $\mathrm{m} 171.067$ & 171.067 & $\mathrm{C}_{8} \mathrm{H}_{10} \mathrm{O}_{4} \mathrm{H}^{+}$ & 150 & $26,(0.0,20,58)$ & 0.351 & $2.33 \%(4)$ \\
\hline $\mathrm{m} 181.100$ & 181.100 & $\begin{array}{l}\mathrm{C}_{14} \mathrm{H}_{12} \mathrm{H}^{+}(-1.0), \\
\mathrm{C}_{9} \mathrm{H}_{12} \mathrm{~N}_{2} \mathrm{O}_{2} \mathrm{H}^{+}(3.0), \\
\mathrm{C}_{5} \mathrm{H}_{13} \mathrm{~N}_{3} \mathrm{O}_{4} \mathrm{H}^{+}(-1.1)\end{array}$ & 150 & $8.8,(0.16,7.1,20.6)$ & 0.510 & $0.79 \%(32)$ \\
\hline $\mathrm{m} 183.083$ & 183.083 & $\begin{array}{l}\mathrm{C}_{13} \mathrm{H}_{10} \mathrm{OH}^{+}(2.8), \\
\mathrm{C}_{9} \mathrm{H}_{11} \mathrm{NO}_{3} \mathrm{H}^{+}(-1.3), \\
\mathrm{C}_{4} \mathrm{H}_{11} \mathrm{~N}_{3} \mathrm{O}_{5} \mathrm{H}^{+}(2.7), \\
\mathrm{C}_{10} \mathrm{H}_{14} \mathrm{OSH}^{+}(-0.6)\end{array}$ & 150 & $12.9,(0.15,7.9,30.0)$ & 0.138 & $1.16 \%(18)$ \\
\hline $\mathrm{m} 185.082$ & 185.082 & $\mathrm{C}_{9} \mathrm{H}_{12} \mathrm{O}_{4} \mathrm{H}^{+}$ & 150 & $11.1,(-0.02,7.3,26.6)$ & 0.298 & $0.99 \%(22))$ \\
\hline
\end{tabular}

\section{Results and discussion}

Figure 3 depicts the 1210 mass-peaks of the "unified-peaklist" where the fractional deviation from the integer mass (yaxis) is plotted against the integer mass (x-axis). The pattern of rising lines clearly stands out and these peaks can unequivocally be attributed to pure hydrocarbons (see insert in Fig. 3). While subsequent analysis showed that most of these peaks were rather instrumental background than original aerosol compounds, we exploited their clear-cut identification for a re-calibration of our mass scale (see Appendix E).

In Fig. 3 the identified peaks are printed in blue (aerosol compounds) and black (other compounds). The peaks for which no empirical formula could be found often exhibit a relatively large mass defect (grey/cyan points, low on the yaxis in Fig. 3). Potentially this can mean that these compounds are highly oxygenated ( $>8$ oxygen atoms, our library contained species with up to eight oxygen atoms). However, we do not think that we are missing a significant fraction of highly oxygenated compounds because only very few compounds were detected with more than 5 oxygen atoms. For compounds present in aerosols we found 16 species with 68 oxygen atoms and 402 species with 1-5 oxygen atoms, respectively. Therefore we think that a significant fraction of the detected compounds contains additional atoms - most likely fluorine, chlorine or other halogens.

\subsection{Compounds detected in aerosols/detection limit}

The cycling of the instrument between gas inlet, aerosol inlet, background, and field blank measurements is illustrated in Fig. 2. Basically, every aerosol sample analysis was followed by a field blank measurement. Because aerosol inlet A had contamination issues on many mass peaks only results from aerosol inlet B are discussed in this section. Aerosol B samples were collected 3 times per day: 04:20-07:06, 12:20-15:06, and 20:20-23:06, respectively. Note that during the first days of the campaign (before day 202; i.e. 22 July 2009) different sampling times were used and field blanks were only measured every fourth aerosol run. In the course of the campaign 120 aerosol measurements were completed with aerosol inlet B and are further analysed. In order to extract the signal that can be attributed to aerosols we linearly interpolated and subtracted the signal of the two neighbouring field blank measurement. In this way we computed background corrected data series of all 1210 detected mass peaks. A compound was considered to be present in aerosols 
(referred to as aerosol compounds hereafter) when the signal was above the detection limit (i) for at least $40 \%$ of the measurements (i.e. 48 of the 120 aerosol analyses), and (ii) this holds for at least two extraction temperatures of the CTD cell. Figure 4 gives examples for the course of concentrations of 4 aerosol species $\left(\mathrm{C}_{4} \mathrm{H}_{4} \mathrm{O}_{3} \mathrm{H}^{+}, \mathrm{C}_{2} \mathrm{H}_{4} \mathrm{OH}^{+}, \mathrm{C}_{3} \mathrm{H}_{3} \mathrm{NH}^{+}\right.$, and $\left.\mathrm{C}_{16} \mathrm{H}_{22} \mathrm{O}_{4} \mathrm{H}^{+}\right)$at 6 extraction temperatures $(100,150,200$, 250,300 , and $350^{\circ} \mathrm{C}$ ). We omitted the first temperature level $\left(50^{\circ} \mathrm{C}\right)$ because only very few compounds had a significant positive signal at this level.

The determination of a realistic detection limit was not a straightforward task because basic counting statistics of the mass spectrometer detector were not the most important factor limiting the detection of aerosol compounds. Instead, the accurate determination of the background (filed blanks) proved to be much more important. Typically we observed that the field blank signal co-varied with the aerosol signal (see data printed in red in Fig. 4, e.g. $\mathrm{C}_{2} \mathrm{H}_{4} \mathrm{OH}^{+}$at 200 and $250^{\circ} \mathrm{C}$ ). This is not surprising because it is expected that air parcels with a high aerosol load also contain a large burden of semivolatile gas phase compounds. The semivolatile compounds will stick to the inner walls of the CTD-cell and contribute to the signal of the field blank. This contamination can cause a memory effect that continues into clean periods. Therefore for very clean conditions field blank signals were sometimes even higher than the signal of the aerosol sample and negative aerosol signals are computed when subtracting the field blank signal. We exploited the information from these negative data points to calculate a realistic detection limit, which was computed according to

$\operatorname{DetLim}_{\text {mass,temp }}=\operatorname{abs}\left(\operatorname{median}\left(S_{<0}\right)\right)+3 * \operatorname{stdev}\left(S_{<0}\right)$,

where "DetLim mass,temp" is the detection limit of a compound at a certain temperature level of the CTD cell, and $S_{<0}$ is the subset of negative data of the series of 120 aerosol measurements; "abs", "median", and "stdev" are functions to calculate the absolute value, the median value, and the standard deviation, respectively. The calculated detection limits are displayed in Fig. 4 (black lines around zero) and represent realistic margins. Our method failed for some cases were no (or too few) negative values were computed. In these cases no detection limit could be calculated but obviously these compounds were generally above the detection limit. Note that the detection limits calculated according to Eq. (4) are usually much higher than the error resulting from counting statistics of the detector.

Applying the above outlined criteria we detected 638 compounds that are present in aerosols. A full list is provided in the supplemental information. Table 1 gives information on 50 compounds, i.e. the compounds with the highest (40 compounds) and lowest (10 compounds) mean concentration. The lowest detected concentrations were in the range of $10 \mathrm{pg} \mathrm{m}^{-3}$. The corresponding detection limits were typically $2-3 \mathrm{pg} \mathrm{m}^{-3}$. The highest detected concentrations were in the range of $100 \mathrm{ng} \mathrm{m}^{-3}$ with typical detection limits below $1 \mathrm{ng} \mathrm{m}^{-3}$. The concentrations of the detected aerosol compounds span a range of 5 orders of magnitude.

The bulk mass of most compounds is released at the $150{ }^{\circ} \mathrm{C}$ and $200{ }^{\circ} \mathrm{C}$ temperature levels of the CTD cell an example is $\mathrm{C}_{4} \mathrm{H}_{4} \mathrm{O}_{3} \mathrm{H}^{+}$(m101.025) in Fig. 4. These are probably semivolatile monomers which are evaporated as soon as their vapour pressure becomes sufficiently high. Other species such as $\mathrm{C}_{2} \mathrm{H}_{4} \mathrm{OH}^{+}$(m45.0336 in Fig. 4) are readily volatilized at all temperatures. These species are typically of relatively low molecular weight and therefore they are very unlikely to be present in aerosol as monomers. We hypothesize that they are fragments which are bound components of oligomeric structures in the aerosol that progressively break free as the CTD temperature rises. Similar argumentation holds for low molecular weight compounds that are released predominantly at high temperatures (e.g. $\mathrm{C}_{3} \mathrm{H}_{3} \mathrm{NH}^{+}$in Fig. 4): due to their relatively low molecular weight they are probably not original aerosol compounds. Instead, they may be formed by thermal decomposition or by pyrolytical processes. A puzzling behaviour is observed for $\mathrm{C}_{16} \mathrm{H}_{22} \mathrm{O}_{4} \mathrm{H}^{+}$- the fourth ion species shown in Fig. 4. While there is a significantly positive aerosol signal observed at CTD cell temperatures of 100 and $150^{\circ} \mathrm{C}$, the signal of the field blanks was higher than the aerosol sample signal for temperatures of $200^{\circ} \mathrm{C}$ and above. At this point we have no conclusive explanation for this. We hypothesise that during field blank sampling semivolatile gas phase compounds may be efficiently trapped on the residuals of previous aerosol analyses of which a major constituent is black carbon. During an aerosol sampling cycle this highly adsorbing surface gets quickly coated with wet aerosols and thus less contamination from semivolatile gas phase compounds is actually present. This behaviour could result in over-correction of the contamination from gas phase compounds and is therefore of potential concern.

\subsection{Total measured organics and its elemental composition}

The technique presented here produces a wealth of data and it will be the subject of future work to fully exploit this information to gain insight into production and processing of aerosols. While individual compounds can be further explored to identify unique tracers for certain sources and/or processes, the road to success is more likely the development of products that yield information on physicochemical processing or are comparable with other aerosol measurements. For laboratory produced secondary organic aerosol Holzinger et al. (2010) have shown good agreement between the total aerosol mass as measured with TD-PTR-MS and a scanning mobility particle sizer (SMPS), respectively. Using the superior mass resolution capabilities of the time of flight mass filter, in addition to total aerosol organic mass we 

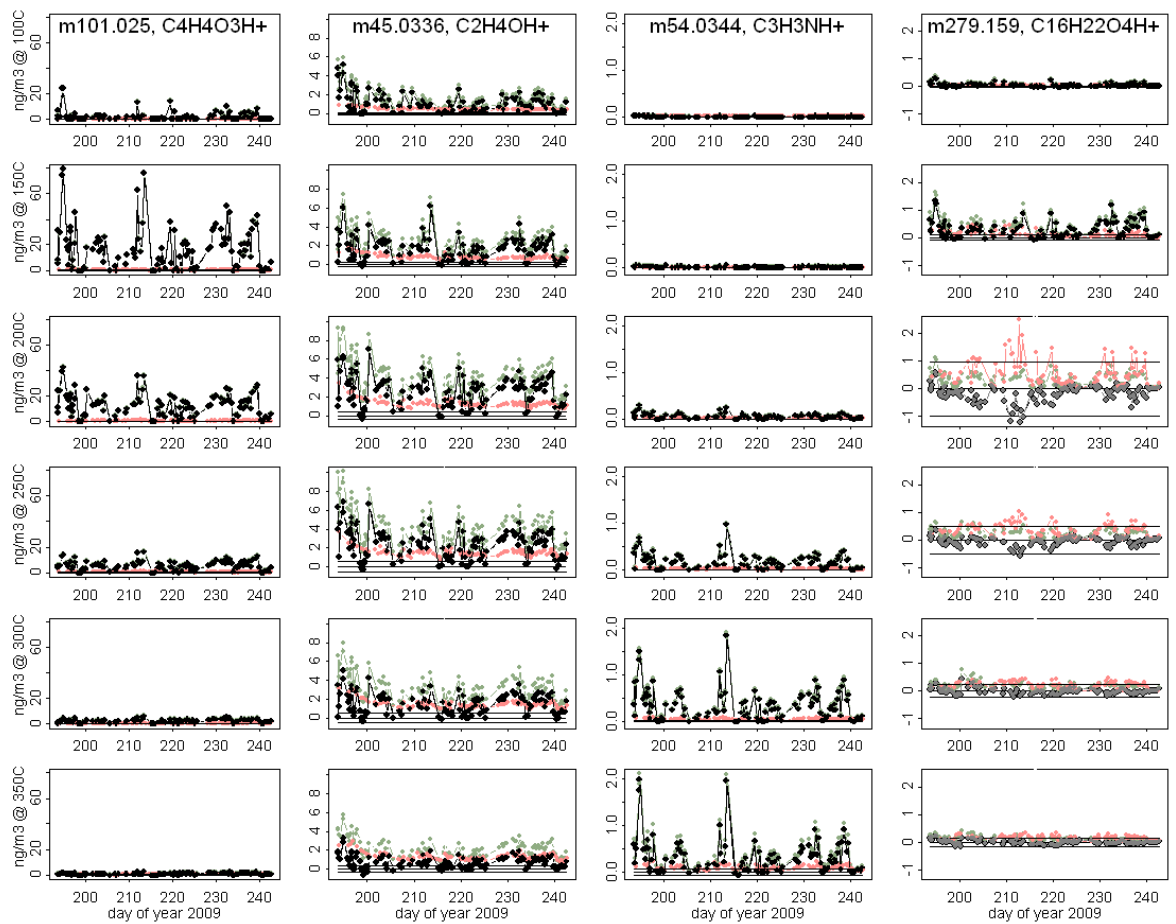

Fig. 4. Temporal evolution of the concentration of 4 aerosol compounds. The rows represent the concentration measured at CTD-cell temperatures of $100^{\circ} \mathrm{C}$ (upper most panels) to $350^{\circ} \mathrm{C}$ (bottom panels). Aerosol sample data are printed in green, and field blank data are printed in red. The aerosol signal (i.e. the difference between field blank and aerosol sample data) is printed in black. The grey datasets represent aerosol signals that are not significantly above the detection limit. The black lines around the zero-line represent the detection limit. See text for further discussion.

can compute the fractions of carbon, oxygen, nitrogen, and sulfur, respectively.

Of the 638 aerosol compounds detected, 15 have been attributed to inorganic species; among these protonated ammonia is the most significant species. With an average concentration of $90 \mathrm{ng} \mathrm{m}^{-3}$ it is the single most abundant species detected in aerosol. Most likely it originates from the thermal decomposition of ammonium sulfate and ammonium bisulfate. The reaction starts at temperatures of $100^{\circ} \mathrm{C}$ which is consistent with the observed thermograms of protonated ammonium. The average concentration of all inorganic compounds was $93 \mathrm{ng} \mathrm{m}^{-3}$ which is $\sim 8 \%$ of the total measured burden. Oxygenated hydrocarbons constitute the bulk of the detected aerosol mass (75\%) followed by organic nitrogen compounds $(9 \%)$, inorganic compounds, unidentified/halogenated (3.8\%), hydrocarbons $(2.7 \%)$, and organic sulfur compounds $(0.8 \%)$.

Figure 5a shows the course of measured total organic compounds and the atomic ratio of oxygen to carbon atoms $(\mathrm{O} / \mathrm{C})$ and nitrogen to carbon atoms (N/C), respectively, together with some meteorological parameters. Note that the $\mathrm{O} / \mathrm{C}$ and $\mathrm{N} / \mathrm{C}$ ratios have been calculated on basis measured ionic species; no corrections for biases resulting from fragmentation or other processes have been applied.
During the campaign 6 extended episodes (marked by the red lines in Fig. 5a) have been identified which are separated by short periods of very low concentrations of organic aerosols that coincide with minimum temperatures. With exception of the first episode (day 190-198) (9.-17.7), ramp structures with increasing aerosol concentrations and sharp drops towards the end of an episode are typically observed and can be clearly seen in the episodes around days 210 (29 July), 230 (18 August), and 238 (26 August). During the first episode we measured the highest aerosol concentrations and relatively low fractions of oxygen. Both consistent with the idea that episode 1 was strongly influenced from local fresh emissions that were convected to the site which is also confirmed by meteorological data. Vertical mixing at the period (day 190-198) was characterized by a temperature profile reaching lapse rate between the village of Rauris (940 m a.s.l., population of 3500) and Sonnnblick (3105 ma.s.l.) on all of these days and weak winds from North, which favoured the advection of local air masses from the nearby valleys.

Surprisingly, the oxygen to carbon ratio was low throughout the campaign (mean 0.38) and exhibited little variation. Almost for all measurements the $\mathrm{O} / \mathrm{C}$ ratio was in the range $0.33-0.48$ (5\% and $95 \%$ percentiles). While the computed $\mathrm{O} / \mathrm{C}$ ratio is a relatively robust number indicating the $\mathrm{O} / \mathrm{C}$ of 
A

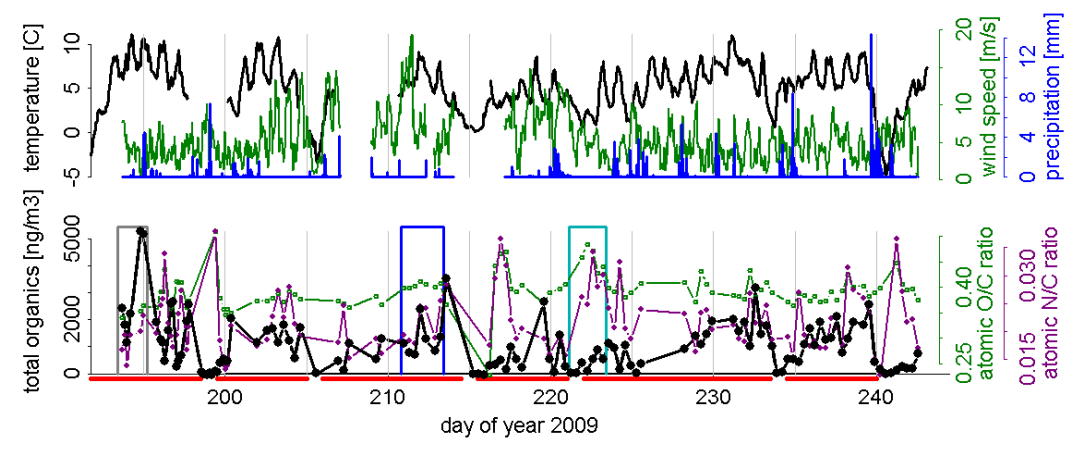

B

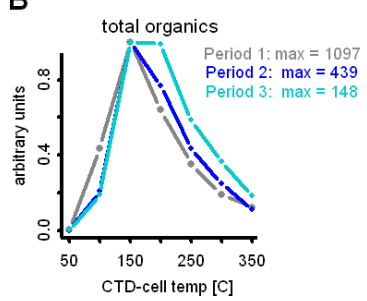

C
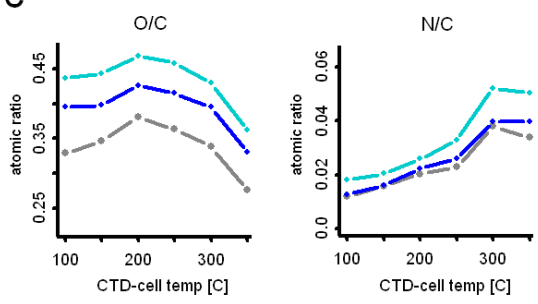

Fig. 5. (A) shows the sum of all organic compounds, the atomic ratios $\mathrm{O} / \mathrm{C}$ and N/C, and some meteorological data throughout the campaign. (B) shows a thermogram of the total detected organic material for 3 selected periods which are marked in (A). The data are normalized to the highest concentration the value (in $\mathrm{ng} \mathrm{m}^{-3}$ ) of which is given in the legend. Panel $\mathrm{C}$ gives the thermogram information for the ratios $\mathrm{O} / \mathrm{C}$ and N/C for the same three periods.

the total detected ion signal, this number cannot be directly translated to the $\mathrm{O} / \mathrm{C}$ ratio of organic aerosols for at least two reasons: firstly, a typical fragmentation pattern during protonation of organic compounds is the ejection of a neutral oxygenated fragment (e.g. $\mathrm{H}_{2} \mathrm{O}$ ). Therefore the neutral fragments (which are not detected in the mass spectrometer) contain disproportionately more oxygen which is missing in the ion signal. To assess how much oxygen may be lost due to fragmentation in the chemical ionization chamber of the instrument we assumed that every ion that has been detected has lost one $\mathrm{H}_{2} \mathrm{O}$ fragment, that is, we increased the number of oxygen atoms by one for each individual ionic species detected. $\mathrm{O} / \mathrm{C}$ ratios calculated in this way certainly represent an overestimation and yielded a mean value of 0.56 which is still low for the $\mathrm{O} / \mathrm{C}$ ratios in organic aerosols. Aiken et al. (2008) analysed O/C ratios over Mexico City and measured values close to 0.6 in the outflow air of the city and 0.7 were typical values for regional pollution. At a remote location such as the Sonnblick observatory we would expect organic aerosol to be significantly more oxidized than in the highly populated area of Mexico City. The second mechanism that may remove oxygen from the aerosol fraction that is actually detected in the mass spectrometer is the removal of oxygen via pyrolytical processes (also known as charring). This process is probably much more relevant than biased fractionation during ionization in the PTR-MS. Charring produces $\mathrm{CO}$ and $\mathrm{CO}_{2}$. Because carbon monoxide and carbon dioxide have proton affinities lower than water these compounds cannot be efficiently detected by the PTR-MS and thus oxygen is removed without being quantified. Note that the oxygen to form $\mathrm{CO}$ and $\mathrm{CO}_{2}$ must come from aerosol oxygen because we used pure nitrogen as carrier gas to transfer evaporated compounds from the CTD cell to the PTRMS.

Despite significant losses of oxygen, there is an inverse relationship between the measured oxygen fraction and the measured total organics: higher fractions of oxygen are associated with low organic aerosol concentrations and presumably more aged aerosol loads; and lower oxygen fractions were measured at times of higher concentrations and presumably less aged aerosol levels.

It is also worth exploring the measured N/C ratio which is in the range 1.2-3.2\% (5\% and 95\% percentiles, see Fig. 5a). The total organic aerosol mass and the fraction of nitrogen are often strongly anti-correlated when neighbouring data points are considered (e.g. days 196-198 in Fig. 5a), however the correlation vanishes if all data are included. This may indicate that the organic nitrogen compounds potentially can be traced back to particular aerosol sources or a distinct physicochemical history. This is in contrast to the degree of oxygenation of aerosols which is believed to be primarily an effect of general aerosol ageing. In absolute numbers we detected a mean concentration of $17 \mathrm{ngN} / \mathrm{m}^{3}$ during the campaign which is $\sim 2.1 \%$ of the organic carbon that was 
detected. It is interesting to note that this number matches reasonably well with the findings of Lin et al. (2010), who measured organic nitrogen at a rural forest site in the US and found an atomic N/C ratio of $\sim 5 \%$ in $\mathrm{PM}_{2.5}$.

\subsection{Information from thermograms}

Figure $5 \mathrm{~b}$ shows average thermograms of the total mass of all measured organic compounds for 3 distinct periods marked in Fig. 5a. The period 1 features the highest aerosol concentrations and relatively low $\mathrm{O} / \mathrm{C}$ ratios; period 3 features low aerosol concentrations and high $\mathrm{O} / \mathrm{C}$ ratios, and period 2 features stable average conditions which are not extreme in that aspect. Maximum concentrations of 1097, 439, and $148 \mathrm{ng} \mathrm{m}^{-3}$ were measured at a CTD-cell temperature of $150^{\circ} \mathrm{C}$ for periods 1,2 , and 3 , respectively. For better comparison the data are normalized to their maximum concentration in Fig. 5b. Figure 5c shows the atomic O/C and N/C ratios as a function of CTD-cell temperature for the same three periods.

The thermograms shown in Fig. 5b are consistent with the criteria on which the periods have been selected. Organic aerosol compounds evaporate at the lower temperatures during period 1 than during the other periods. Low oxygen fractions were calculated and this period is a subset of episode 1 which was influenced by young local/regional aerosol pollution. In contrast during period 3 aerosol organics evaporate at higher temperatures, which is consistent with the higher oxygen fraction. The thermogram of the reference period 2 is between the more extreme cases of period 1 and 3 .

Despite the difference in the oxygen fractions during the 3 periods, their relative courses as a function of CTD-cell temperature are very similar (Fig. $5 \mathrm{c}$ ): the $\mathrm{O} / \mathrm{C}$ ratio increases with increasing CTD-cell temperatures up to $200^{\circ} \mathrm{C}$. Above, this threshold the fraction of oxygen is decreasing. The decreasing behaviour is surprising because less volatile compounds should contain more oxygen functional groups (Pankow and Asher, 2008) and we would expect an increasing line of the oxygen fraction throughout the displayed temperature range. Therefore we think that a significant fraction of the oxygen is lost at higher temperatures and this is actually consistent with the hypothesis that we miss a significant fraction of the oxygen due to charring. An alternative explanation is that there exist exceedingly low volatility compounds with high carbon numbers, but closer inspection of our data reveals no further evidence for such compounds.

The fraction of nitrogen is increasing with increasing CTD cell temperature for all 3 periods. Many nitrogen containing compounds exhibit a similar behaviour as $\mathrm{C}_{3} \mathrm{H}_{3} \mathrm{NH}^{+}$(shown in Fig. 4) which consequently results in the rising line of the nitrogen fraction in Fig. 5c. Rollins et al. (2009) performed chamber experiments of isoprene with $\mathrm{NO}_{3}$ and observed high SOA production from alkyl nitrates which could also hold for other hydrocarbons that are oxidized in polluted $\mathrm{NO}_{3}$ rich environments. While several of the identified species possibly can be attributed to alkyl nitrates, the increase of N/C at higher temperatures suggests that a significant fraction of the detected nitrogen does originate from less volatile compounds. This is not only suggested by the measured thermograms but also by the fact that many of the most abundant nitrogen compounds are not original monomeric aerosol species but are thermal decomposition products such as $\mathrm{C}_{3} \mathrm{H}_{3} \mathrm{NH}^{+}$. Nevertheless, the bulk of organic nitrogen is released at temperatures of $100-200{ }^{\circ} \mathrm{C}$ and alkyl nitrates may still be the most significant contribution to the burden of organic nitrogen compounds.

\subsection{Comparison with $\mathrm{OC}$ from Hi-vol filter samples}

The data of total organic carbon were averaged to match the periods of high volume filter sampling which provides an opportunity of inter-comparison of the TD-PTR-MS data with the OC analysis from filter samples which is a well established and commonly used technique. The results are shown in Table 2. The datasets are well correlated $\left(r^{2}=0.8\right)$ and the TD-PTR-MS data are on average $\sim 25 \%$ lower than OC from the filter samples. Some of the variability is probably due to different sampling times. While the filters are continuously sampled over $24 \mathrm{~h}$, the TD-PTR-MS sampled only $\sim 7 \mathrm{~h}$ per day. At first glance the agreement looks good, however, given the known processes that reduce the detectable fraction of carbon it is striking that the agreement is within margins of 20-30\%. The processes we consider are: (i) charring, which produces $\mathrm{CO}_{2}$, i.e. carbon that cannot be detected with PTR-MS, (ii) the maximum temperature of the CTDcell is not high enough to vaporize $100 \%$ of the organic carbon, and (iii) fragmentation during ionization. It is not possible to quantify these loss processes at this point, however, preliminary crude estimates suggest that more than $50 \%$ of the OC could be lost. On the other hand positive and negative sampling artefacts have also been reported for filter samples (Subramanian et al., 2004). Especially for long sampling periods ( $>24 \mathrm{~h}$ ) evaporative losses of semivolatile compounds could represent a significant negative sampling effect.

\section{Conclusions and outlook}

We presented first results of data obtained with a high mass resolution TD-PTR-MS instrument at the remote Mt. Sonnblick observatory. A major challenge was to process the huge amount of data that were collected and therefore special attention is given to the description of the most important evaluation routines in Appendices A-E. We showed that a large fraction of organic aerosols can be directly measured and quantified with the new system thus gaining valuable insights into sources and processing of organic aerosol. The presented analytical approach is a young technique and there is ample potential for improvement of both the physical instrument and data processing. As for improvements 
Table 2. Results of an OC/EC analysis of filter samples and OC values derived from TD-PTR-MS. Units are $\mathrm{ng} \mathrm{m}^{-3}$.

\begin{tabular}{lrrrrr}
\hline & \multicolumn{3}{c}{ HiVol filter } & \multicolumn{2}{c}{ TD-PTR-MS } \\
date (2009) & doy & TC & EC & OC & OC \\
\hline 13-20 Jul & $193-199$ & 1289 & 413 & 876 & 793 \\
20-27 Jul & $200-206$ & 1038 & 375 & 664 & 628 \\
3-10 Aug & $214-220$ & 585 & 216 & 368 & 307 \\
10-17 Aug & $221-227$ & 716 & 293 & 422 & 261 \\
17-24 Aug & $228-234$ & 1431 & 398 & 1033 & 743 \\
24-31 Aug & $235-241$ & 1320 & 401 & 919 & 589 \\
\hline
\end{tabular}

on the instrument, most important would be a higher operation temperature of the PTR-MS drift tube and the transfer lines. A promising prototype of a high temperature drift tube was recently presented by Mikoviny et al. (2010) and could improve the performance of the instrument. As for data analysis, the peak detection routines can be improved by non-linear least square modeling of overlapping peaks. Peak attribution can be improved by including organic halogenated compounds to the compound library, and erroneous attribution of empirical formulas to observed signals can be minimized by exploiting the natural abundances of isotopologues.

\section{Appendix A}

\section{Mass scale calibration}

The time an ion needs to traverse the TOF region follows the simple relation

$t=t_{0}+a \sqrt{m}$,

where a and $t_{0}$ are parameters that depend on the dimensions of the TOF mass spectrometer and time lags associated with the counting electronics, respectively. The relation is simple, however, due to thermal expansion of the instrument (and possibly other reasons) the flight time of a single ion is subject to fractional variations and therefore the parameters ( $a$, $\left.t_{0}\right)$ slightly change over time. The correct value of the parameters can be calculated by evaluating the arrival times $\left(t_{1}\right.$, $\left.t_{2}\right)$ of two peaks with a known mass $\left(m_{1}, m_{2}\right)$ :

$t_{0}=\frac{t_{2} \sqrt{m_{1}}-t_{1} \sqrt{m_{2}}}{\sqrt{m_{1}}-\sqrt{m_{2}}}$

$a=\frac{t_{1}-t_{0}}{\sqrt{m_{1}}}$

A practical requirement for peaks used for calibration are that they should (i) cover a wide mass range, (ii) always be present at relatively constant levels, and (iii) there should not be highly variable, adjacent signals. Therefore the natural choice is to select a set of background peaks that are always present in the mass spectrum. During aerosol analysis most instrumental background peaks, however, interfered with compounds evaporating from the CTD cell but the signals at masses $29.997(\mathrm{NO}+$ ) and 286.973 (unidentified contamination) proved to be an appropriate set for performing a mass scale calibration. The signal at the high mass was low and therefore we evaluated the data by forming running means over $10 \mathrm{~min}$ periods (120 cycles), which should not introduce systematic errors because the drifting of the parameters a and $t_{0}$ (mostly due to thermal expansion of the instrument) is on slower timescales. After isolating the calibration peaks, we identified the center of the peak by nonlinear-least-squares fitting to a Gauss-type function including offset, a linear and a quadratic term. The parameters " $a$ " and " $t_{0}$ " were thus calculated for each cycle of the dataset and were used to attach the correct mass scale to each measured cycle.

\section{Appendix B}

\section{Peak detection}

A peak search routine was applied to each data file. For the peak detection we used the sum-spectrum and the median of the corresponding mass scale calibration parameters $\left(a, t_{0}\right)$.

The peak search routine identified peaks by scanning through the derivative of the smoothed sum-spectrum (the smoothing window width was 5 data points). A potential peak was detected whenever the routine detected a point that jumped out of the local noise. A useful threshold was that such a point had to be larger than 8 times the $75 \%$ percentile of the previous 200 data points. After a potential peak had been detected, peak-center, start and the end of the peak were determined as follows: the position where the derivative stands out of the noise defines the start; the peak-center is where the derivative crosses the zero-line and becomes negative; the end of the peak is defined at the position where the derivative (after passing a minimum) is back at noise level. In order to exclude false peaks, originating for example from single spikes in the dataset, detected peaks were only added to the peak-list when the mass of the peak-center divided by the width (end-start) was in the range 200-10 000. Typically 400-1000 peaks in the mass range 17-430 Da were detected in individual data files.

\section{Appendix C}

\section{Homogenization of the individual peak lists - the unified-peak-list}

Considering a mass resolution of 5000, the width of ion signals detected at masses 100,200 , and $300 \mathrm{Da}$ is 20,40 , and $60 \mathrm{mDa}$, respectively. Because of this typical broadness the 

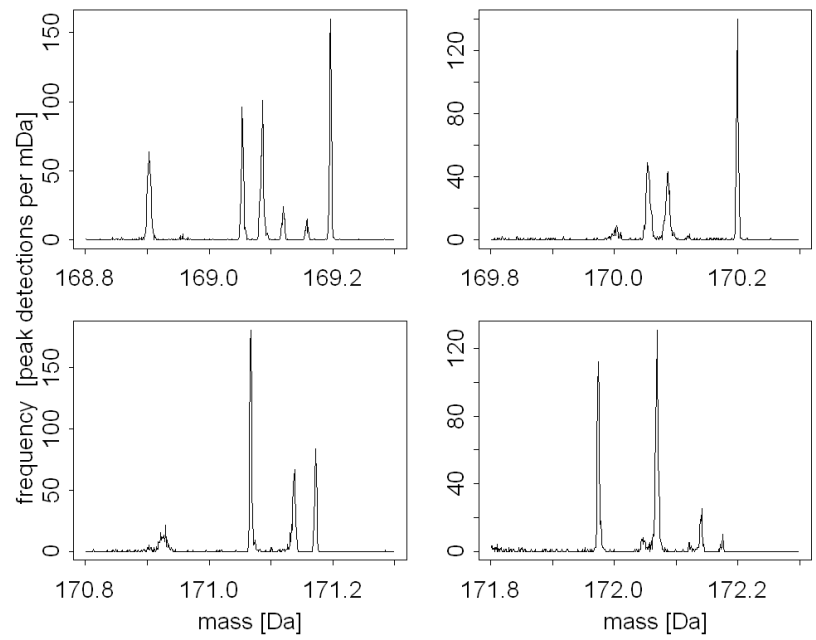

Fig. C1. Peaks detected at nominal masses 169-172. The peak lists of all 1022 data files have been evaluated. The x-axis is a binmass scale ( $1 \mathrm{mDa}$ bin width); the y-axis gives the number of files in which a peak was detected in the respective bin. The unified-peaklist was created from this dataset.

center of the peak could not always be determined at sub$\mathrm{mDa}$ accuracy levels. This holds particularly for higher mass numbers and low intensity signals. For our 75 min evaluation periods the error is typically a few mDa. To determine the mass of the compounds at the best possible accuracy we performed a statistical evaluation of the 1022 individual "Peak lists" that were created from the raw data collected during the campaign. The first step of this procedure was to sort the detected peaks of all files on a new mass scale consisting of 430000 bins with a width of $1 \mathrm{mDa}$ that covered the range $0-430 \mathrm{Da}$. If a peak of a peak list fell into a certain mDa-bin, the count of that bin was increased by 1 . Theoretically, the maximum count number on one bin can thus be 1022, which would mean that in all files the peak is detected in the same mDa-bin; practically the highest numbers were in the range 100-800. Examples of this treatment are shown in Fig. C1. Peaks caused by one particular compound show a sharp Gaussian-type distribution and the center of such a distribution represents the most accurate mass assignment of the peak. In a second step the "unified-peak-list" is created from the Gaussian-type count distributions on the new "1mDa-bin" mass scale.

\section{Appendix D}

Peak integration, calculation of concentration, accuracy, and correction of overlapping peaks

An analysis of a representative set of peaks showed that the peak shape was nearly Gaussian and that the mass resolution power (defined as ratio of mass and the full width at

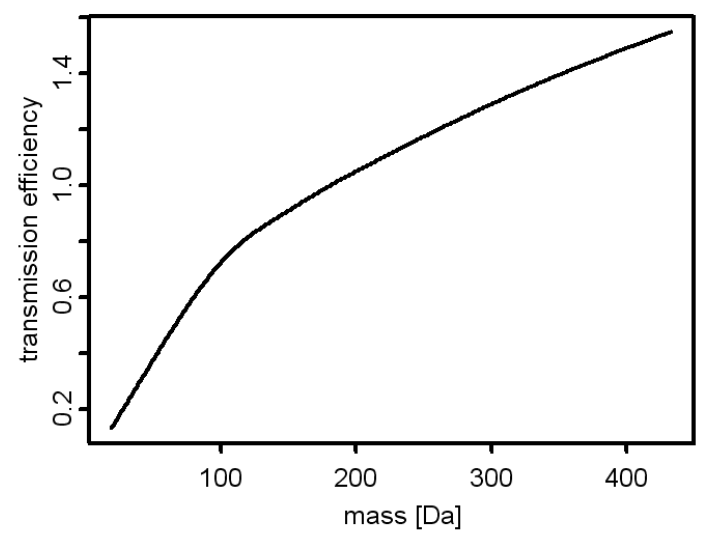

Fig. D1. Fractional transmission efficiency of the PTR-TOF-MS system.

half maximum, FWHM) of the TOF-MS was in the range 3500-5000 throughout the campaign, where lower resolutions were associated with masses below $100 \mathrm{Da}$ and the higher values were typical for masses above this threshold. To calculate appropriate integration boundaries for the mass peaks we assumed Gaussian peaks and a mass resolution of 4000. The integration boundaries were then set at a distance of $\pm 2 \sigma$ from the center of the peak. In case the boundaries of neighbouring peaks were overlapping, we symmetrically decreased the overlapping area to zero. Herewith we avoided double counting of signal; however, overlapping peaks contributed to their neighbour-peaks and in extreme cases the entire signal could come from their overlapping neighbour(s). A correction procedure for this interference will be described below. In the future a routine for non-linear least-squares fitting of overlapping peaks will provide a better solution because it also allows extracting hidden peaks. For the present analysis, all counts within the integration boundaries are summed up and form the signal (in counts) of the respective mass-peak.

The concentration of aerosol compounds and volume mixing ratios of gas phase compounds were calculated from the count signal of primary ions and product ions according to the method described in Holzinger et al. (2010). Briefly, gas phase mixing ratios and aerosol concentrations are calculated directly from (i) instrumental parameters such as voltages, flows, pressures, and the transmission efficiency of the PTRTOF system, (ii) default reaction rate constants for exothermic proton transfer reactions, and (iii) the ratio of the signals of the respective mass peaks and the primary $\mathrm{H}_{3} \mathrm{O}^{+}$ions. Figure D1 shows the fractional transmission efficiency (provided by Ionicon Inc.) that has been used for all calculations. The accuracy of the transmission efficiency should be better than $\pm 25 \%$. For exothermic proton transfer reactions the reaction rate constant is usually within the range 2$4 \times 10^{-9} \mathrm{~cm}^{3} \mathrm{~s}^{-1}$ where lower values typically apply to lower molecular weight pure hydrocarbons and higher values apply 


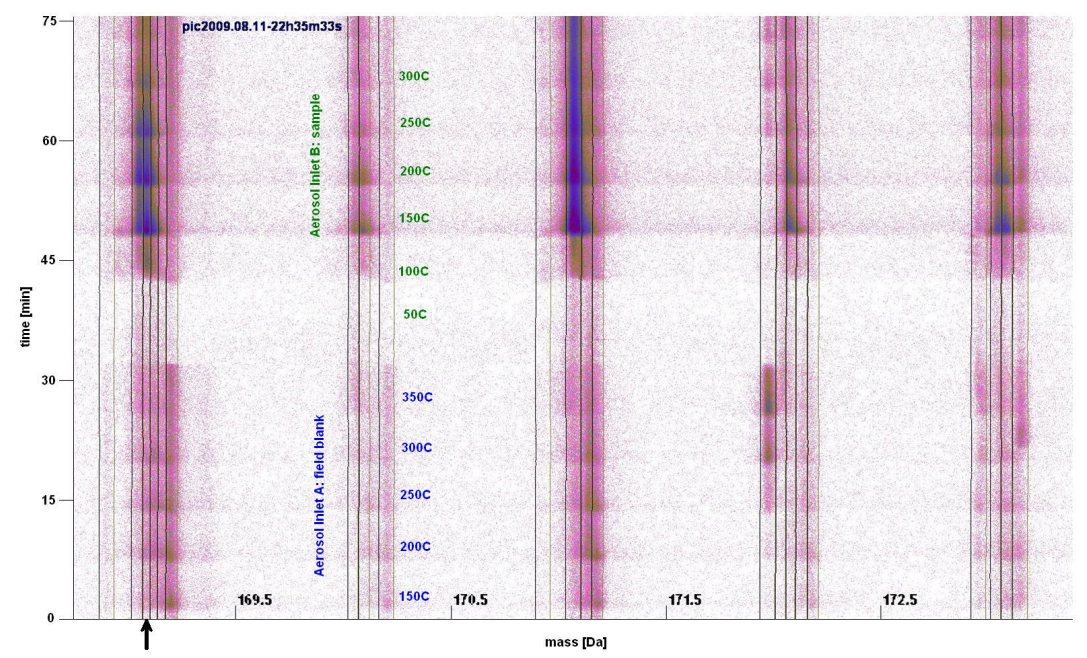

Fig. D2. Image of raw TOF-MS data covering the signals of five nominal masses (169-173 Da) over a 75 min period starting on 11 August 2009 at 22:35. The data show measurements of an aerosol field blank from inlet "A" and aerosol sample from inlet "B". The color code scales with the logarithm of the counts detected by the mass spectrometer and covers approximately five orders of magnitude. Also shown as vertical lines are the integration boundaries for the peaks from the "unified-peak-list"; the low and high mass margins are printed in black and brown, respectively. Some brown lines are not visible because they are to close to the following black line. The arrow at the $\mathrm{x}$-axis marks the interval of mass 169.085 Da the data of which are also included in the insert of Fig. 2.
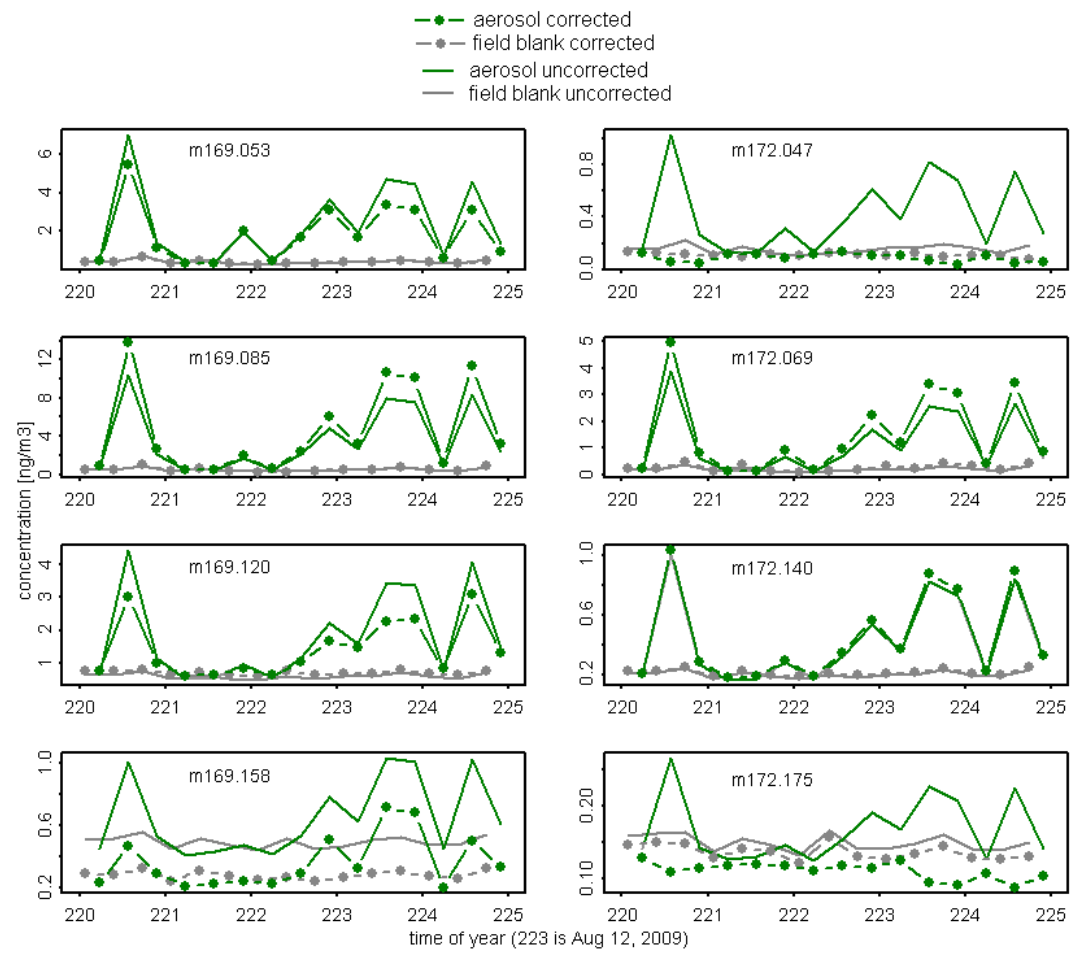

Fig. D3. Five day time series of ions detected at nominal masses 169 and 172 (Aerosol inlet B). Data printed in grey represent field blank measurements; data printed in green are aerosol sample data. Solid lines are uncorrected data and the series with symbols have been corrected for the signal from overlapping neighbouring peaks. After correction, all four peaks detected at mass 169 are still enhanced in aerosols. At mass 172 only two compounds are present in aerosols (masses 172.069 and 172.140 Da). The signals detected at masses 172.047 and 172.175 were entirely attributed to their overlapping neighbours. After the correction their signals were no longer above the field blank measurements. 
to heavier oxygenated species. While Holzinger et al., 2010 used a default value of $2 \times 10^{-9} \mathrm{~cm}^{3} \mathrm{~s}^{-1}$ (recommended by Ionicon Inc.) we think that a higher value of $3 \times 10^{-9} \mathrm{~cm}^{3} \mathrm{~s}^{-1}$ is more realistic for the burden of compounds detected in this study and consequently we used this value as a default for the reaction rate constant. Actually we think that the new (higher) default value of the reaction rate constant could still be somewhat too low given the high degree of oxygenated compounds that is encountered in aged aerosol. However, we are confident that the accuracy of the reaction rate constant is within a $\pm 30 \%$ margin for the vast majority of the detected compounds. Using a higher reaction rate constant of $3 \times 10^{-9} \mathrm{~cm}^{3} \mathrm{~s}^{-1}$ (instead of $2 \times 10^{-9} \mathrm{~cm}^{3} \mathrm{~s}^{-1}$ ) straightforwardly results in lower concentrations and mixing ratios (by a factor 2/3). The total accuracy of the data of single ion species presented here should be better than $\pm 60 \%$.

Figure D2 illustrates data processing by showing a typical series of raw data (covering $75 \mathrm{~min}$, i.e. 900 cycles) for a small section of the mass spectrum $(168.5-173.5 \mathrm{Da})$. The color code in the Figure represents the logarithm of the detected counts of the TOF mass spectrometer. The mass scale has been computed by the time-to-mass routine. The integration boundaries (black line start, brownish line end) for all peaks detected in the range (from the "unified-peak-list") are also shown in Fig. D2. The shown period represents a field blank analysis of the aerosol inlet A and a sample analysis of inlet B. Within the integration boundaries all detected counts are summed up and form the raw signal of a compound as shown in Fig. 2. From Fig. D2 it is obvious that the compounds are not fully separated (e.g. peaks around $169 \mathrm{Da}$, minutes 45-60). Therefore a correction procedure for overlapping signals is important.

In order to reduce the computational expense the correction of overlapping peaks was done on averaged data. For gas phase measurements we averaged 180 cycles (which represents $15 \mathrm{~min}$ averages) and for aerosol measurements we averaged all data from a temperature level (72 cycles, $6 \mathrm{~min}$ ). Assuming Gaussian peak shapes and a mass resolution of 4000 we calculated the fractional contribution of overlapping peaks to the signals of their neighbour(s). Mathematically, this represents a system of coupled linear equations which was solved using the IDL "LUSOL" function. Figure D3 shows the results of this correction on overlapping peaks detected at nominal masses 169 and $172 \mathrm{Da}$. A general rule is that the peaks with a higher signal gain from peaks with a lower signal. In the case of masses 172.047 and 172.175 Da the corrected sample signal is no longer above the signal of the field blanks. Therefore these two peaks were not present in collected particles in the 5 day period shown in Fig. D3. All analysis presented in the "results and discussion" section was done with the corrected dataset. The strength of the presented method is that it provides a robust and quick correction of overlapping signals. As to the weaknesses, the accuracy is limited because we do not perform a thorough peak shape and fitting analysis, which may result in
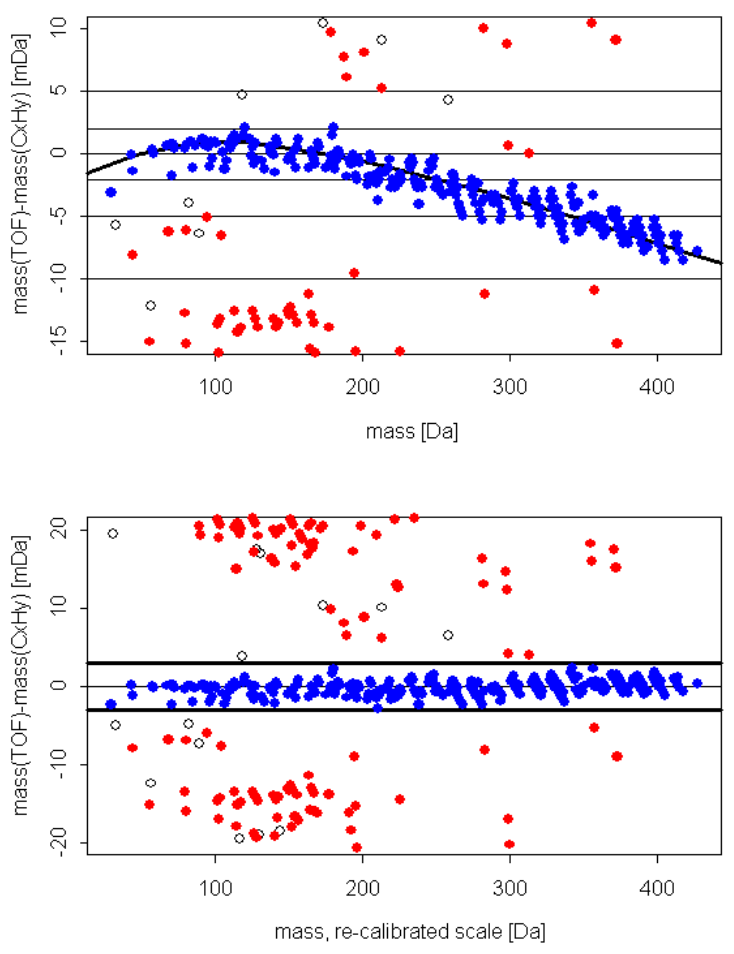

Fig. E1. Re-calibration of the mass scale. (a) shows the difference between the detected mass and the best match with the mass of a pure hydrocarbon. The peaks printed in blue identified hydrocarbon peaks (also see Fig. 3); peaks printed in red and black (open cycles) were identified non-hydrocarbon peaks and unidentified peaks, respectively. The spline function through the points was used to re-calibrate the mass scale. Panel (b) shows the same for the re-calibrated mass scale. The accuracy of the detected masses is better than $\pm 3 \mathrm{mDa}$ (bold lines in $\mathrm{b}$ ).

both under- and overcorrection. Our choice of 4000 for the mass resolution is conservative because mass peaks above 80-90 Da were typically better resolved than that (resolution $\sim 5000$ ). Therefore for most cases we overcorrected overlapping peaks, which may mean that our procedures failed to identify some low signal aerosol compounds if their neighbouring peaks exhibited a comparably large signal.

\section{Appendix E}

\section{Mass scale re-calibration and peak identification}

The mass spectra clearly showed homologous series of hydrocarbons (Fig. 3). We exploit their clear-cut identification to recalibrate the mass scale and improve the accuracy of measured $\mathrm{m} / \mathrm{z}$ values of the detected peaks. Figure E1a shows the fractional mass difference between the detected peaks and the mass of the protonated pure hydrocarbon ion which is closest to the mass of the respective peak. For the hydrocarbon peaks the fractional mass difference is within 
$\pm 2 \mathrm{mDa}$ up to an $\mathrm{m} / \mathrm{z}$ ratio of $\sim 180 \mathrm{Da}$. For larger masses the deviation increases, at $400 \mathrm{Da}$ typical values are -5 to $-9 \mathrm{Da}$. Figure E1 a also shows the spline function (bold black line) through the hydrocarbon peaks which was used to recalibrate the mass scale. Figure E1b shows that after recalibration all hydrocarbon peaks are within a band of $\pm 3 \mathrm{mDa}$ throughout the whole mass scale. Thus we used a tolerance of $\pm 3 \mathrm{mDa}$ for the attribution of empirical formulas to the measured peaks.

As first step for mass peak attribution we created a database of possible empirical formulas. We used the free "MF-finder" tool (Michal Krompiec and Luc Patiny, http://www.chemcalc.org) to calculate molecular formulas of carbon, hydrogen, oxygen, and nitrogen, containing 0 $35,0-72,0-8$, and $0-3$ atoms, respectively. The list was extended by adding $\sim 1800$ organic sulphur compounds from the NIST chemistry webbook (http://webbook.nist.gov/ chemistry). Our database comprises about 18000 molecular formulas, and the exact protonated masses of their two most abundant isotopologues. E.g. for benzene $\left(\mathrm{C}_{6} \mathrm{H}_{6}\right)$ these are the masses of ${ }^{12} \mathrm{C}_{6}^{1} \mathrm{H}_{6}^{1} \mathrm{H}^{+}$(79.0542 Da), and ${ }^{13} \mathrm{C}^{12} \mathrm{C}_{5}^{1} \mathrm{H}_{6}^{1} \mathrm{H}^{+}$ ( $80.0576 \mathrm{Da})$, respectively. 841 of the 1210 detected peaks could be attributed to an empirical formula within the tolerance level of $\pm 3 \mathrm{mDa}$. For 302 peaks more than one empirical formula matched within the tolerance margins. Two molecular formulas were found for 235 peaks; three for 59, and four for 8 peaks, respectively. In case of multiple peak attribution we considered oxygenated hydrocarbons to be the most likely candidate, followed by pure hydrocarbons, nitrogen compounds and sulphur compounds. This ranking is important to keep in mind for interpreting the analysis of the $\mathrm{C} / \mathrm{O} / \mathrm{N} / \mathrm{S}$ fractions of the aerosol burden in the "results and discussion" section. For example, for mass 183.083 $\mathrm{Da}$ we found 4 empirical formulas, i.e. $\mathrm{C}_{13} \mathrm{H}_{10} \mathrm{OH}^{+}$, $\mathrm{C}_{9} \mathrm{H}_{11} \mathrm{NO}_{3} \mathrm{H}^{+}, \mathrm{C}_{4} \mathrm{H}_{11} \mathrm{~N}_{3} \mathrm{O}_{5} \mathrm{H}^{+}$, and $\mathrm{C}_{10} \mathrm{H}_{14} \mathrm{OSH}^{+}$. According to our ranking we attributed the signal at this mass completely to $\mathrm{C}_{13} \mathrm{H}_{10} \mathrm{OH}^{+}$. That means that we potentially underestimate the nitrogen and sulfur fraction of the total measured burden if mass 183.083 is actually one of the other species.

The peak identification presented in this section only relies on the measured mass. As described above this yielded ambiguous results for almost $40 \%$ of the peaks. In future versions of the evaluation routines we will aim at reducing the ambiguity by exploiting the natural abundance of isotopologues.

\section{Supplementary material related to this article is available online at: http://www.atmos-chem-phys.net/10/10111/2010/ acp-10-10111-2010-supplement.pdf.}

Acknowledgements. This work has been funded by The Netherlands Organization for Scientific Research (NWO) under the ALW-Middelgroot program (Grant 834.08.002). Insightful comments on this work have been provided by Neil Donahue. We gratefully acknowledge this input.

Edited by: J. Thornton

\section{References}

Aiken, A. C., DeCarlo, P. F., and Jimenez, J. L.: Elemental analysis of organic species with electron ionization high-resolution mass spectrometry, Anal. Chem., 79, 8350-8358, 2007.

Aiken, A. C., Decarlo, P. F., Kroll, J. H., Worsnop, D. R., Huffman, J. A., Docherty, K. S., Ulbrich, I. M., Mohr, C., Kimmel, J. R., Sueper, D., Sun, Y., Zhang, Q., Trimborn, A., Northway, M., Ziemann, P. J., Canagaratna, M. R., Onasch, T. B., Alfarra, M. R., Prevot, A. S. H., Dommen, J., Duplissy, J., Metzger, A., Baltensperger, U., and Jimenez, J. L.: O/C and OM/OC ratios of primary, secondary, and ambient organic aerosols with high-resolution time-of-flight aerosol mass spectrometry, Environ. Sci. Technol., 42, 4478-4485, 2008.

Andreae, M. O. and Crutzen, P. J.: Atmospheric aerosols: Biogeochemical sources and role in atmospheric chemistry, Science, 276, 1052-1058, 1997.

Andreae, M. O. and Rosenfeld, D.: Aerosol-cloud-precipitation interactions. Part 1. The nature and sources of cloud-active aerosols, Earth-Sci. Rev., 89, 13-41, 2008.

Bascom, R., Bromberg, P. A., Costa, D. A., Devlin, R., Dockery, D. W., Frampton, M. W., Lambert, W., Samet, J. M., Speizer, F. E., and Utell, M.: Health effects of outdoor air pollution, American Journal of Respiratory and Critical Care Medicine, 153, 3-50, 1996.

Cachier, H., Bremond, M. P., and Buat-Menard, P.: Determination of atmospheric soot carbon with a simple thermal method, Tellus, 41B, 379-390, 1989.

Charlson, R. J., Schwartz, S. E., Hales, J. M., Cess, R. D., Coakley, J. A., Hansen, J. E., and Hofmann, D. J.: Climate Forcing by Anthropogenic Aerosols, Science, 255, 423-430, 1992.

DeCarlo, P. F., Kimmel, J. R., Trimborn, A., Northway, M. J., Jayne, J. T., Aiken, A. C., Gonin, M., Fuhrer, K., Horvath, T., Docherty, K. S., Worsnop, D. R., and Jimenez, J. L.: Field-deployable, high-resolution, time-of-flight aerosol mass spectrometer, Anal. Chem., 78, 8281-8289, 2006.

Donahue, N. M., Robinson, A. L., Stanier, C. O., and Pandis, S. N.: Coupled partitioning, dilution, and chemical aging of semivolatile organics, Environ. Sci. Technol., 40, 2635-2643, 2006.

Goldstein, A. H. and Galbally, I. E.: Known and unexplored organic constituents in the earth's atmosphere, Environ. Sci. Technol., 41, 1514-1521, 2007.

Graus, M., Muller, M., and Hansel, A.: High Resolution PTR-TOF: Quantification and Formula Confirmation of VOC in Real Time, J. Am. Soc. Mass Spectrom., 21, 1037-1044, 2010.

Hallquist, M., Wenger, J. C., Baltensperger, U., Rudich, Y., Simpson, D., Claeys, M., Dommen, J., Donahue, N. M., George, C., Goldstein, A. H., Hamilton, J. F., Herrmann, H., Hoffmann, T., Iinuma, Y., Jang, M., Jenkin, M. E., Jimenez, J. L., Kiendler-Scharr, A., Maenhaut, W., McFiggans, G., Mentel, Th. 
F., Monod, A., Prvt, A. S. H., Seinfeld, J. H., Surratt, J. D., Szmigielski, R., and Wildt, J.: The formation, properties and impact of secondary organic aerosol: current and emerging issues, Atmos. Chem. Phys., 9, 5155-5236, doi:10.5194/acp-95155-2009, 2009.

Hansel, A., Jordan, A., Warneke, C., Holzinger, R., Wisthaler, A., and Lindinger, W.: Proton-transfer-reaction mass spectrometry (PTR-MS): on-line monitoring of volatile organic compounds at volume mixing ratios of a few pptv, Plasma Sources Science \& Technology, 8, 332-336, 1999.

Hellen, H., Dommen, J., Metzger, A., Gascho, A., Duplissy, J., Tritscher, T., Prevot, A. S. H., and Baltensperger, U.: Using proton transfer reaction mass spectrometry for online analysis of secondary organic aerosols, Environ. Sci. Technol., 42, 73477353,2008

Holzinger, R., Williams, J., Herrmann, F., Lelieveld, J., Donahue, N. M., and Rckmann, T.: Aerosol analysis using a ThermalDesorption Proton-Transfer-Reaction Mass Spectrometer (TDPTR-MS): a new approach to study processing of organic aerosols, Atmos. Chem. Phys., 10, 2257-2267, doi:10.5194/acp10-2257-2010, 2010.

Jacobson, M. Z.: Strong radiative heating due to the mixing state of black carbon in atmospheric aerosols, Nature, 409, 695-697, 2001.

Jankowski, N., Schmidl, Ch., Marr, I., Bauer, H., and Puxbaum, H.: Comparison of methods for the quantification of carbonate carbon in atmospheric PM10 aerosol samples, Atmos. Environ., 42, 8055-8064, 2008

Jayne, J. T., Leard, D. C., Zhang, X. F., Davidovits, P., Smith, K. A., Kolb, C. E., and Worsnop, D. R.: Development of an aerosol mass spectrometer for size and composition analysis of submicron particles, Aerosol Sci. Technol., 33, 49-70, 2000.

Jimenez, J. L., Canagaratna, M. R., Donahue, N. M., Prevot, A. S. H., Zhang, Q., Kroll, J. H., DeCarlo, P. F., Allan, J. D., Coe, H., Ng, N. L., Aiken, A. C., Docherty, K. S., Ulbrich, I. M., Grieshop, A. P., Robinson, A. L., Duplissy, J., Smith, J. D., Wilson, K. R., Lanz, V. A., Hueglin, C., Sun, Y. L., Tian, J., Laaksonen, A., Raatikainen, T., Rautiainen, J., Vaattovaara, P., Ehn, M., Kulmala, M., Tomlinson, J. M., Collins, D. R., Cubison, M. J., Dunlea, E. J., Huffman, J. A., Onasch, T. B., Alfarra, M. R., Williams, P. I., Bower, K., Kondo, Y., Schneider, J., Drewnick, F., Borrmann, S., Weimer, S., Demerjian, K., Salcedo, D., Cottrell, L., Griffin, R., Takami, A., Miyoshi, T., Hatakeyama, S., Shimono, A., Sun, J. Y., Zhang, Y. M., Dzepina, K., Kimmel, J. R., Sueper, D., Jayne, J. T., Herndon, S. C., Trimborn, A. M., Williams, L. R., Wood, E. C., Middlebrook, A. M., Kolb, C. E., Baltensperger, U., and Worsnop, D. R.: Evolution of Organic Aerosols in the Atmosphere, Science, 326, 1525-1529, 2009.

Jobson, B. T., Alexander, M. L., Maupin, G. D., and Muntean, G. G.: On-line analysis of organic compounds in diesel exhaust using a proton transfer reaction mass spectrometer (PTR-MS), Int. J. Mass Spectrom., 245, 78-89, 2005.

Jordan, A., Haidacher, S., Hanel, G., Hartungen, E., Mark, L., Seehauser, H., Schottkowsky, R., Sulzer, P., and Mark, T. D.: A high resolution and high sensitivity proton-transfer-reaction time-of-flight mass spectrometer (PTR-TOF-MS), Int. J. Mass Spectrom., 286, 122-128, 2009.
Kanakidou, M., Seinfeld, J. H., Pandis, S. N., Barnes, I., Dentener, F. J., Facchini, M. C., Van Dingenen, R., Ervens, B., Nenes, A., Nielsen, C. J., Swietlicki, E., Putaud, J. P., Balkanski, Y., Fuzzi, S., Horth, J., Moortgat, G. K., Winterhalter, R., Myhre, C. E. L., Tsigaridis, K., Vignati, E., Stephanou, E. G., and Wilson, J.: Organic aerosol and global climate modelling: a review, Atmos. Chem. Phys., 5, 1053-1123, doi:10.5194/acp-5-1053-2005, 2005.

Lin, M., Walker, J., Geron, C., and Khlystov, A.: Organic nitrogen in $\mathrm{PM}_{2.5}$ aerosol at a forest site in the Southeast US, Atmos. Chem. Phys., 10, 2145-2157, doi:10.5194/acp-10-21452010, 2010.

Lindinger, W., Hansel, A., and Jordan, A.: On-line monitoring of volatile organic compounds at pptv levels by means of protontransfer-reaction mass spectrometry (PTR-MS) - Medical applications, food control and environmental research, Int. J. Mass Spectrom., 173, 191-241, 1998.

Mikoviny, T., Kaser, L., and Wisthaler, A.: Development and characterization of a High-Temperature Proton-Transfer-Reaction Mass Spectrometer (HT-PTR-MS), Atmos. Meas. Tech. Discuss., 3, 185-202, doi:10.5194/amtd-3-185-2010, 2010.

Müller, M., Graus, M., Ruuskanen, T. M., Schnitzhofer, R., Bamberger, I., Kaser, L., Titzmann, T., Hörtnagl, L., Wohlfahrt, G., Karl, T., and Hansel, A.: First eddy covariance flux measurements by PTR-TOF, Atmos. Meas. Tech., 3, 387-395, doi:10.5194/amt-3-387-2010, 2010.

Pankow, J. F. and Asher, W. E.: SIMPOL.1: a simple group contribution method for predicting vapor pressures and enthalpies of vaporization of multifunctional organic compounds, Atmos. Chem. Phys., 8, 2773-2796, doi:10.5194/acp-8-27732008, 2008.

Pöschl, U.: Atmospheric aerosols: Composition, transformation, climate and health effects, Angewandte Chemie-International Edition, 44, 7520-7540, 2005.

Ramanathan, V. and Carmichael, G.: Global and regional climate changes due to black carbon, Nature Geosci., 1, 221-227, 2008.

Ramanathan, V., Crutzen, P. J., Kiehl, J. T., and Rosenfeld, D.: Atmosphere - Aerosols, climate, and the hydrological cycle, Science, 294, 2119-2124, 2001.

Robinson, A. L., Donahue, N. M., Shrivastava, M. K., Weitkamp, E. A., Sage, A. M., Grieshop, A. P., Lane, T. E., Pierce, J. R., and Pandis, S. N.: Rethinking organic aerosols: Semivolatile emissions and photochemical aging, Science, 315, 1259-1262, 2007.

Rollins, A. W., Kiendler-Scharr, A., Fry, J. L., Brauers, T., Brown, S. S., Dorn, H.-P., Dubé, W. P., Fuchs, H., Mensah, A., Mentel, T. F., Rohrer, F., Tillmann, R., Wegener, R., Wooldridge, P. J., and Cohen, R. C.: Isoprene oxidation by nitrate radical: alkyl nitrate and secondary organic aerosol yields, Atmos. Chem. Phys., 9, 6685-6703, doi:10.5194/acp-9-6685-2009, 2009.

Rosenfeld, D., Lohmann, U., Raga, G. B., O’Dowd, C. D., Kulmala, M., Fuzzi, S., Reissell, A., and Andreae, M. O.: Flood or drought: How do aerosols affect precipitation?, Science, 321, 1309-1313, 2008.

Subramanian, R., Khlystov, A. Y., Cabada, J. C., and Robinson, A. L.: Positive and negative artifacts in particulate organic carbon measurements with denuded and undenuded sampler configurations, Aerosol Sci. Technol., 38, 27-48, 2004. 
Williams, B., Goldstein, A., Kreisberg, N., and Hering, S.: An in-situ instrument for speciated organic composition of atmospheric aerosols: Thermal desorption aerosol GC/MS-FID (TAG), Aerosol Sci. Technol., 40, 627-638, 2006.
Zhao, J. and Zhang, R. Y.: Proton transfer reaction rate constants between hydronium ion $(\mathrm{H} 3 \mathrm{O}(+))$ and volatile organic compounds, Atmos. Environ., 38, 2177-2185, 2004. 